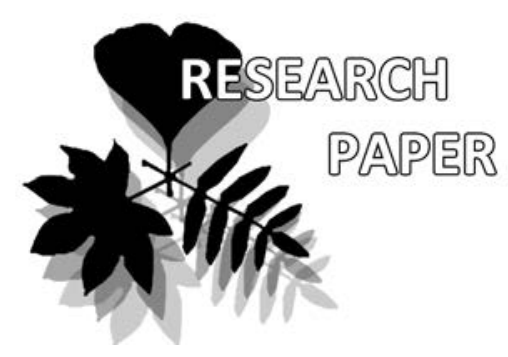

Bülent Şahin ${ }^{1}$

e-mail: bsahin@trabzon.edu.tr

Bülent Akar ${ }^{2}$

e-mail: akarblnt@gmal.com

Sophia Barinova ${ }^{3 *}$

e-mail: sophia@evo.haifa.ac.il

${ }^{1}$ Department of Biology Education, Fatih Education Faculty, Trabzon University, Sögütlü-Trabzon, Turkey

${ }^{2}$ Department of Food Engineering, Faculty of Engineering and

Natural Sciences, Gümüşhane University, Gümüșhane, Turkey

${ }^{3}$ Institute of Evolution,

University of Haifa, Haifa, Israel

* corresponding author

Manuscript received: 23.12.2019

Review completed: 08.06.2020

Accepted for publication: 15.06.2020

Published online: 18.06.2020

Electronic Appendix:

http://www.geobotanica.ru/bp/ 2020_09_02/BP_2020_9_2_sahin_app_ A1.pdf

\section{Non-diatom algae of the high mountain protected lakes in the Artabel Lakes Nature Park, Gümüşhane, Turkey}

\author{
Bülent Şahin ${ }^{1}$, Bülent Akar $^{2}$, Sophia Barinova ${ }^{3 *}$
}

\begin{abstract}
A B S T R A C T
For the first time, we studied 18 lakes of the Artabel Lakes Nature Park and revealed 154 species of non-diatoms algae from four taxonomic Divisions. Charophyta (73 taxa) prevails in the flora and mainly represented by the genus Cosmarium (37). Cyanobacteria (42), Chlorophyta (30) and Eunlenozoa (9) are also present. New records for the Turkish algae flora are represented by 31 taxa, most of which belong to Cosmarium (15) and Staurastrum (5). Rare species from benthic cyanobacteria were revealed in communities of the Artabel Lake. Statistical methods revealed a high individuality of the algae communities and divided it into two major group: Acambol-Yıldız, and Beş-Artabel, which belong to different River Basins. The altitude of the lakes appears to be the major environmental variable that controls the non-diatom algal diversity. Bioindication characterized the water of studied lakes as temperate by temperature, middle saturated with oxygen, neutral to low acidic $\mathrm{pH}$, low saline, Class 2-3 of Water Quality and mesotrophic.
\end{abstract}

K e y w o r d s : non-diatom algae, bioindication, high mountain lakes, Artabel Lakes Nature Park, Turkey

\section{P E 3 Ю M E}

Сахин, Б., Акар, Б., Баринова, С. Недиатомовые водоросли высокогорных охраняемых озер Природного Парка Артабель Аэйкс, Гюмюшхане, Турция. Впервые исследовано 18 озер природного парка Артабельских озер. Было идентифицировано 154 вида недиатомовых водорослей из четырех таксономических отделов. Представители отдела Charophyta (73 таксона) преобладают в основном за счет видов рода Cosmarium (37). Также представлены отделы Cyanobacteria (42), Chlorophyta (30) и Eunlenozoa (9). Новые находки Аля флоры водорослей Турции представлены 31 таксоном, большинство из которых принадлежит родам Cosmarium (15) и Staurastrum (5). Редкие виды цианобактерий найдены в сообществах озера Артабель. Статистические методы выявили высокую индивиАуальность сообществ водорослей и разделили их на Аве основные группы: Акамболь - Йымдыз и Беш-Артабель, относящиеся к разным речным бассейнам. Высота озер явАяется основной переменной среды, которая регулирует разнообразие неАиатомовых водорослей. Биоиндикация позволила характеризовать воду исследуемых озер как умеренную по температуре, умеренно насыщенную кис Аородом, от нейтрального АО низкого кислотного рН, с низким содержанием солей, 2-3 класса качества и мезотрофную.

Ключевые слова: недиатомовые водоросли, биоиндикация, высокогорные озера, Природный Парк Артабель Аэйкс, Турция
High mountain lakes are ecosystems with extreme living conditions. The first is the low $\mathrm{pH}$, followed by the lack of nutrients, and low temperature. Moreover, intensive UV radiation or darkness for months makes high mountain lakes extraordinary habitats. Such extreme conditions are the reason why many species of algae live only in high mountain lakes (Psenner 2003). Therefore, it is very important to know about algal diversity in the high mountain lakes because they can be used as environmental indicators (Barinova \& Krupa 2017). One of the parameters of the aquatic ecosystem used in the ecological evaluation of water quality is also algae (Stevenson 2014, Bellinger \& Sigee 2010). Therefore, many algal species are used as environmental indicators. Diatoms, especially, are ones of the important alive groups of benthic communities, and that is why they are usually an indispensable element of the water quality determination studies (Ács et al. 2004). According to the literature (Coesel 1984, Borics et al. 1998, Feher 2003), several species of desmids are also closely related to certain types of aquatic habitats and may be used as indicators of changes in $\mathrm{pH}$ or nutrient supply. In addition, Coesel (1998) expresses that desmids are excellent bio-indicators for the stability of ecosystems.

Bio-indication approaches for waters monitoring are used in many countries during the recent years (Barinova et al. 2006, 2013, Barinova \& Fahima 2017, Jienbekov et al. 2018, Barinova \& Niyatbekov 2018, 2019). Barinova (2011) noted that this method gives efficient results in ecological assessment of water quality. In the bio-indication studies performed in Turkey, diatom communities were generally used (Solak et al. 2012, Sivac1 et al. 2013). In this study, for the ecological evaluation of the water ecosystems in the 
Artabel Lakes Nature Park we used non-diatom algae communities first time in Turkey.

The main characteristics of the Eastern Black Sea region are the high mountains and temperate climate. Also, the region has an extensive water network with many rivers, lakes, and ponds. Moreover, these habitats are far from industrial and human influences. These conditions contribute to the formation of rich algal diversity in the region. In these waters, for many centuries, a special community of algae (especially desmids) adapted to extreme environmental conditions has formed and developed (Şahin 1998, 2000, 2001, 2002, 2003, 2004, 2008, Şahin \& Akar 2005, Akar \& Şahin 2006, Kolaylı \& Şahin 2009, Şahin et al. 2010). However, there are still many high mountain lakes in the Eastern Black Sea Region, which are unknown for algal diversity. Artabel Lakes Nature Park is one of the most important natural parks in the region. It includes 23 high mountain lakes. Atıc1 (2018) published the first written record concerning algae of these lakes.

This study focuses on the assessment of the taxonomic diversity of non-diatom algae and the current ecological state of high-altitude lakes in the Artabel Lakes Nature Park using statistical, comparative floristic, and bioindication methods, to identify environmental variables that control the development of algal communities in alpine protected areas.

\section{Study site description}

The Ministry of Forestry of the Republic of Turkey declared Artabel Lakes as Nature Park in 1998. The park is located between latitudes $40^{\circ} 21^{\prime} 36^{\prime \prime}$ and $40^{\circ} 26^{\prime} 42^{\prime \prime} \mathrm{N}$ and longitudes $39^{\circ} 00^{\prime} 24^{\prime \prime}$ and $39^{\circ} 08^{\prime} 23^{\prime \prime} \mathrm{E}$ within the boundary of Gümüşhane province in the north of Turkey. The park territory with an area 5859 ha had formed as the result of volcanic activities at different geologic epochs. There are four types of soil: bare rocks, debris, high mountain meadow, and non-calcareous brown soil, in the park. The climate of the region is semi-arid and moist. In terms of average temperature values of the area, while it is $-3^{\circ} \mathrm{C}$ at $3000 \mathrm{~m}$ above sea level (a.s.l.), the mean temperature at the lower parts of the park at $2100 \mathrm{~m}$ a.s.l. is $4^{\circ} \mathrm{C}$ higher (Doğa Koruma ve Milli Parklar Genel Müdürlüğü 2013).

Artabel Lakes Nature Park includes terrestrial and aquatic ecosystems with rich biodiversity, so it has an important place in protected areas in Turkey. In the area, there are endemic taxa listed in the International Nature Conservation Union (IUCN) and the Berne Convention Annex I, II and III (Doğa Koruma ve Milli Parklar Genel Müdürlüğü 2013).

The area includes three river basins. These are Gümüştuğ River basin (Kara and Beş Lakes), Artabel River basin (Artabel Lakes), and Kongel River basin (Ylldı and Acembol Lakes). The total basin area is approximately $58.2 \mathrm{~km}^{2}$, and it composed of five different lake sites including Artabel Lakes (ARL), Acembol Lakes (ACL), Beş Lakes (BL), Kara Lakes (KL) and Yildız Lakes (YL). There are 23 lakes, which belong to Artabel Lakes (6), Acembol Lakes (3), Beş Lakes (5), Kara Lakes (6), and Yildız Lakes (3). Some of the different size lakes have been linked to each other or are independent (Doğa Koruma ve Milli Parklar Genel Müdürlüğü 2013). There is also a previously unnamed lake (Isimsiz Lake: IL) and a small pond (Yildız Lakes Pond (YLP)) (Fig. 1).

\section{MATERIAL AND METHODS Sampling}

Within the scope of this research, the lakes in the Artabel Lakes Nature Park were visited two times. The first visit took place on 15 August 2013. Algae and water samples were taken from Artabel (ARL) and Beş (BL) Lakes. The second visit was made on 13 August 2016 and samples were taken from Acembol (ACL) and Yildız (YL) Lakes, İsimsiz Lake (IL) and Yıldız Lakes Pond (YLP). Kara Lakes could not be visited, because the terrain conditions were difficult. Also, there was no water in the Lake BL5, so algal and water samples could not be taken. In total, 43 epipelic, epilithic and epiphytic algae samples were taken from 17 lakes and a pond. Epipelic samples were collected employing a glass tube from a sediment surface at all the water bodies except Lake BL2 (Round, 1953; Sládečková 1962). Epilithic samples were taken from ARL1, ARL2, BL2, ACL1, ACL2, ACL3, and IL lakes. Randomly chosen stones were scraped with a toothbrush and then washed into plastic bottles. For epiphytic samples, mosses (Hygrobypnum luridum (Hedwig) Jennings (1913:287)) and filamentous alga (Microspora Thuret 1850) were taken from ARL1, ARL3, YL1, YL2, YL3, ACL2, ACL3, IL lakes, and YLP Pond. Filamentous green algae such as Microspora, Oedogonium, and Ulothrix were taken by hand. All samples were fixed in a solution of $4 \%$ neutral formaldehyde. In the field, water temperature, $\mathrm{pH}$, dissolved oxygen, total dissolved solids (TDS), and electrical

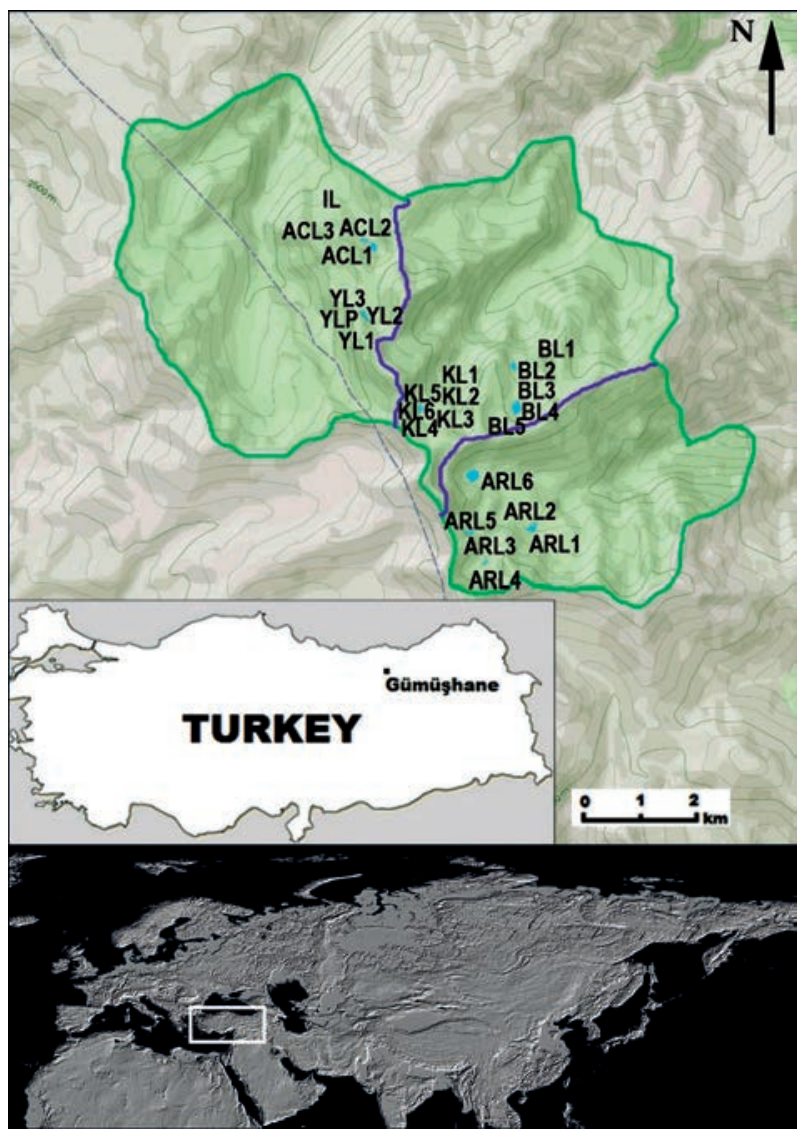

Figure 1 Map of Artabel Lakes Nature Park (Doğa Koruma ve Milli Parklar Genel Müdürlüğu 2013) with three streams basins defined by purple line and places of studied lakes 
conductivity were measured using an Orion4Star and YSI 55 portable measuring instruments at each sampling station. Samples were transported to the laboratory in the icebox.

\section{Laboratory processing}

In the laboratory, samples were examined in temporary slides and under a Leica DM 2500 model light microscope. Algae were photographed with camera Leica DFC 290 attached to the microscope. All of the taxa were identified according to West \& West (1904, 1905, 1908, 1912, 1923), Prescott (1962), Ruzicka (1977), Lind \& Brook (1980), HuberPestalozzi (1982), Dillard (1990, 1991, 1993), Bourrelly \& Coute (1991), Gábor (1995), Lenzenweger (1996, 1997, 1999), John et al. (2003), Komárek \& Anagnostidis (1998, 2005), Wotowski \& Hindak (2005), Hindak (2008), Kadlubowska (2009), Brook \& Williamson (2010), Stastny (2010), Coesel \& Meesters (2007, 2013), Park (2012), Komárek (2013), Kim (2013, 2015), Lee (2015), Vitonyté \& Kasperovičiené (2015). The current status of nomenclature of all the taxa has been checked in the Algaebase web site (Guiry \& Guiry 2019).

Calculation of similarity was doing in the GRAPHS program (Novakovsky 2004) and biological and environmental data relationships analysis were done in the Statistica 12.0 and CANOCO (Ter Braak \& Šmilauer 2002) programs. Bioindication analysis was done with the help of ecological preferences of revealed desmid algae species (Barinova et al. 2006, 2019).

Frequencies of algal taxa were determined according to the following scale based on the number of lakes studied in Artabel Lakes Nature Park. Very rare (1): taxa recorded in $1-20 \%$ of investigated lakes; rare (2): in 21-40\%; common (3): in 41-60\%; frequent (4): in 61-80\%; and very frequent (5): in $81-100 \%$ of investigated lakes (Kocataş 1992).

\section{RESULTS AND DISCUSSION Physical and chemical analyses}

The results of some physical and chemical analyses of the studied waters are given in another paper (Şahin \& Akar 2019a). According to the results (Table 1), waters temperatures ranged from 10.1 to $19.1^{\circ} \mathrm{C}$. The values of the $\mathrm{pH}$ varied from 6.19 to 7.52 . According to the values, the waters of the Artabel Lakes Nature Park are acidic and circumneutral. The concentrations of dissolved oxygen (DO) and total dissolved solids (TDS) varied from 2.10 to $9.45 \mathrm{mg} / \mathrm{L}$ and from 6 to $30.55 \mathrm{mg} / \mathrm{L}$, respectively. The values of water conductivity (C) of the studied waters can be characterized as low $\left(12.0-49.9 \mu \mathrm{Sm} \cdot \mathrm{cm}^{-1}\right)$.

When Table 1 (Şahin et al. 2019b) examined, it is seen that there are linear, negative, strong relationships between altitude and water temperature $(\mathrm{T})(\mathrm{r}=-0.701, \mathrm{p}<0.01)$. This means that as the altitude of the lakes increases, the temperature decreases. There are also linear, negative, moderate relationships between total dissolved solids (TDS) and dissolved oxygen (DO) $(r=-0.574$, $\mathrm{p}<0.01)$. This finding suggests that as the amount of total dissolved solids increases, the amount of dissolved oxygen decreases. Also, it is seen that there are linear, positive, strong relationships between total dissolved solids (TDS) and conductivity $(\mathrm{C})(\mathrm{r}=0.738, \mathrm{p}<0.01)$. This means that as the amount of total dissolved solids increases, the conductivity increases.

\section{Algal flora}

The examination of all samples of epipelic, epilithic and epiphytic from Artabel Lakes Nature Park showed the presence of 154 non-diatom taxa. The systematical structure analyses of algal flora in Artabel Lakes Nature Park revealed Charophyta (73 taxa) as the richest order. The following divisions were Cyanobacteria (42 taxa), Chlorophyta (30 taxa), and Euglenozoa (9 taxa) (Table A1). As a result of the comparison of the benthic communities of the studied lakes were observed differences both in taxon compositions of each lake and relative abundances. Floristically, Charophyta had more diversity than other divisions in each studied water bodies. Qualitatively, the genus Cosmarium was dominant (37 taxa) and Staurastrum (10 taxa) subdominant. While the genera Closterium and Trachelomonas were represented by 7 taxa, the genera Desmodesmus and Oscillatoria were represented by 6 taxa. Whereas, the genera Chroococcus and Merismopedia were represented by 5 taxa each. The other genera were represented by four or less taxa (Table A1).

Despite the fact that the algae in the Artabel Lakes Nature Park were studied for the first time and therefore are new to this protected area, we revealed 32 new taxa (Table A1, asterisk) for the Turkish algae flora (Taşkın 2019). A large number of new records are 26 Charophyta taxa (Şahin 2019), most of which belong to the genera Cosmarium (15) and Staurastrum (5) (Şahin \& Akar 2019a). Three Chlorophyta newly revealed species belong to Chlorococcales and Chlamydomonadales and are commonly distributed taxa, which has been revealed only with a detailed study of collected samples (Şahin \& Akar 2019b). No new taxa from euglenoids whereas three cyanobacteria contain rare species Scytonema coactile and Katagnymene accurate (Şahin \& Akar 2019b).

Table 1. Averaged environmental variables in studied lakes of the Artabel Lakes Nature Park, Turkey in August 2013. The groups of the lakes are toned by a different color. "-", variables were not measured in highest lake

\begin{tabular}{lcccccc}
\hline Lake & $\begin{array}{c}\text { Altitude, } \\
\text { m a.s.l. }\end{array}$ & $\begin{array}{c}\text { Temperature, } \\
{ }^{\mathbf{C}} \mathbf{c}\end{array}$ & $\begin{array}{c}\mathbf{D O}, \\
\mathbf{m g} / \mathbf{L}\end{array}$ & $\mathbf{p H}$ & $\begin{array}{c}\text { TDS, } \\
\mathbf{m g} / \mathbf{L}\end{array}$ & $\begin{array}{c}\text { Conductivity, } \\
\boldsymbol{\mu} \mathbf{S m} / \mathbf{c m}^{-1}\end{array}$ \\
\hline ARL1 & 2687 & 17.5 & 8.71 & 6.19 & 16 & 32.6 \\
ARL2 & 2763 & 16.7 & 8.42 & 6.4 & 22 & 45.5 \\
ARL3 & 2875 & 16.3 & 8.76 & 6.19 & 24 & 49.9 \\
ARL4 & 2890 & 15.7 & 9.45 & 6.73 & 10 & 21.5 \\
ARL5 & 2930 & 12.4 & 8.95 & 7.02 & 13 & 26.2 \\
ARL6 & 2863 & 15.9 & 8.97 & 6.98 & 10 & 21.3 \\
BL1 & 2831 & 13.9 & 9.14 & 7.06 & 10 & 21.4 \\
BL2 & 2863 & 12.5 & 9.32 & 6.75 & 18 & 36.3 \\
BL3 & 2915 & 10.1 & 9.2 & 7.01 & 16 & 33.1 \\
BL4 & 2924 & 15.5 & 8.3 & 7.04 & 6 & 13.2 \\
BL5 & 3015 & - & - & - & - & - \\
ACL1 & 2713 & 15.5 & 3.25 & 7.04 & 24.1 & 30.6 \\
ACL2 & 2712 & 15.3 & 2.1 & 7.09 & 30.6 & 38.5 \\
ACL3 & 2711 & 17.9 & 2.94 & 7.52 & 20.8 & 27.7 \\
YL1 & 2980 & 14.6 & 2.27 & 6.85 & 16.3 & 19.7 \\
YL2 & 2980 & 11.5 & 2.88 & 6.89 & 26.7 & 30.7 \\
YL3 & 2980 & 14.1 & 3.12 & 7.01 & 24.1 & 29.5 \\
YLP & 2980 & 14.5 & 2.34 & 7.2 & 23.4 & 29.2 \\
IL & 2668 & 19.1 & 4.25 & 6.78 & 9.1 & 12.0 \\
\hline
\end{tabular}


Table 2. Distribution of species richness in taxonomic Divisions and average number of indicator taxa over studied lakes of the Artabel Lakes Nature Park, Turkey in August 2013, 2016. Note: Abbreviation of the lakes name: ARL: Artabel Lakes, BL: Beş Lakes, YL: Yıldız Lakes, ACL: Acembol Lakes, IL: İsimsiz Lake, YLP: Yıldız Lakes Pond. Abbreviation of the ecological groups of indicators (Barinova et al. 2006): Habitat preferences (Hab): P - planktonic, P-B - planktonic-benthic, B - benthic, wide range, need some substrate; Ep - epiphytes. Water temperature preferences ( $\mathrm{T})$ : warm - warm-water inhabitants; temp - temperate water temperature inhabitants or indifferent; eterm - eurythermic. Oxygenation indicators (Oxy): st - standing water, st-str - low streaming water, aer - aerophiles. Salinity (Sal): hb - oligohalobes-halophobes, i - oligohalobes-indifferents, $\mathrm{mh}$ - mesohalobes, hl - halophiles. Acidity $(\mathrm{pH})$ degree indicators $(\mathrm{pH})$ : alf - alkaliphiles, ind - indifferents; acf - acidophiles. Trophic state indicators (Tro): o - oligotraphentic; o-m - oligo-mesotraphentic; $\mathrm{m}$ - mesotraphentic; me - meso-eutraphentic; e - eutraphentic. SI: species-specific index saprobity SI.

\begin{tabular}{|c|c|c|c|c|c|c|c|c|c|c|c|c|c|c|c|c|c|c|c|c|c|c|}
\hline \multirow[b]{2}{*}{ Indicator } & \multicolumn{22}{|c|}{ Lake } \\
\hline & $\underset{\beta}{\vec{z}}$ & 疍 & 急 & 泀 & $\frac{13}{2}$ & & $\frac{3}{4}$ & $\vec{A}$ & $\stackrel{\mathcal{D}}{\mathcal{D}}$ & $\stackrel{3}{9}$ & $\stackrel{+}{7}$ & & $\stackrel{n}{\operatorname{n}}$ & $\underset{4}{3}$ & $\underset{ن}{3}$ & 3 & $\vec{Z}$ & $\underset{\mathcal{Z}}{\mathcal{Z}}$ & $\stackrel{3}{3}$ & $\frac{G}{7}$ & & 日 \\
\hline \multicolumn{23}{|l|}{ Taxa } \\
\hline Charophyta & 20 & 0 & 2 & 4 & 5 & & 2 & 8 & 5 & 1 & & 9 & 1 & 8 & 8 & 15 & 9 & 15 & 9 & 9 & 1. & \\
\hline Chlorophyta & 2 & 0 & 1 & 0 & 0 & & 1 & 2 & 2 & 1 & 1 & 1 & 0 & 7 & 9 & 11 & 0 & 6 & 12 & 7 & . & 5 \\
\hline Cyanobacteria & 5 & 4 & 1 & 3 & 2 & & 3 & 3 & 1 & 3 & 3 & 3 & 0 & 4 & 9 & 4 & 5 & 7 & 6 & 9 & 1 & \\
\hline Euglenozoa (Euglenophyta) & 2 & 0 & 1 & 2 & 1 & & 1 & 2 & 0 & 3 & 0 & 0 & 0 & 1 & 1 & 0 & 1 & 2 & 0 & 2 & ? & 1 \\
\hline Species richness & 29 & 4 & 5 & 9 & 8 & & 7 & 15 & 8 & 8 & 13 & & 1 & 20 & 27 & 30 & 15 & 30 & 27 & 27 & 3 & 2 \\
\hline Abundance sum of scores & 55 & 35 & 29 & 21 & 16 & & 1 & 10 & 22 & 21 & 11 & & 14 & 60 & 40 & 57 & 60 & 64 & 31 & 49 & 5 & 5 \\
\hline Index Saprobity SI & 1.58 & 1.75 & 1.63 & 1.84 & 1.98 & 1.60 & & .40 & 2.01 & 1.96 & 1.44 & 41.8 & 851. & 1.88 & 1.56 & 1.38 & 1.63 & 1.59 & 1.81 & 1.74 & 1.9 & \\
\hline \multicolumn{23}{|l|}{ Habitat } \\
\hline B & 17 & 2 & 2 & 4 & 5 & & 1 & 5 & 4 & 1 & & 6 & 1 & 6 & 11 & 10 & 7 & 13 & 8 & 9 & 1. & \\
\hline P-B & 8 & 1 & 2 & 2 & 3 & & 4 & 6 & 3 & 5 & ( & 6 & 0 & 12 & 10 & 14 & 7 & 11 & 8 & 10 & 1 & 1 \\
\hline $\mathrm{P}$ & 1 & 0 & 0 & 0 & 0 & & 0 & 0 & 0 & 0 & 0 & 0 & 0 & 1 & 3 & 3 & 1 & 2 & 2 & 2 & ? & 4 \\
\hline Ep & 0 & 0 & 0 & 0 & 0 & & 0 & 0 & 0 & 0 & $c$ & 0 & 0 & 1 & 1 & 0 & 0 & 0 & 0 & 0 & ) & 1 \\
\hline \multicolumn{23}{|l|}{ Temperature } \\
\hline eterm & 1 & 0 & 1 & 0 & 1 & & 0 & 1 & 0 & 2 & 0 & 0 & 0 & 1 & 0 & 0 & 1 & 1 & 0 & 1 & & 1 \\
\hline warm & 1 & 0 & 0 & 0 & 0 & & 0 & 0 & 0 & 0 & 0 & 0 & 0 & 1 & 1 & 1 & 0 & 0 & 0 & 0 & ) & 0 \\
\hline temp & 0 & 0 & 0 & 0 & 0 & & 0 & 0 & 0 & 0 & 0 & 0 & 0 & 0 & 0 & 0 & 0 & 0 & 0 & 0 & ) & 1 \\
\hline \multicolumn{23}{|l|}{ Oxygen } \\
\hline aer & 2 & 1 & 1 & 0 & 1 & & 0 & 0 & 0 & 1 & & 1 & 0 & 2 & 3 & 2 & 1 & 8 & 7 & 3 & & 1 \\
\hline st & 2 & 0 & 0 & 0 & 0 & & 0 & 0 & 0 & 0 & c & 0 & 0 & 0 & 2 & 0 & 0 & 0 & 0 & 0 & ) & 1 \\
\hline st-str & 3 & 0 & 1 & 3 & 4 & & 2 & 4 & 3 & 5 & 4 & 4 & 0 & 8 & 10 & 8 & 5 & 6 & 5 & 7 & 1 & 0 \\
\hline \multicolumn{23}{|l|}{$\mathrm{pH}$} \\
\hline acf & 10 & 0 & 2 & 0 & 2 & & 0 & 2 & 0 & 0 & & 4 & 0 & 2 & 1 & 5 & 2 & 8 & 4 & 4 & & 2 \\
\hline alf & 0 & 0 & 0 & 0 & 0 & & 0 & 0 & 0 & 0 & 0 & 0 & 0 & 0 & 1 & 0 & 0 & 1 & 1 & 0 & ) & 0 \\
\hline ind & 11 & 0 & 1 & 3 & 4 & & 3 & 8 & 4 & 3 & 6 & 6 & 0 & 10 & 8 & 11 & 8 & 10 & 6 & 7 & 1. & 5 \\
\hline \multicolumn{23}{|l|}{ Salinity } \\
\hline $\mathrm{hb}$ & 3 & 0 & 0 & 0 & 0 & & 0 & 2 & 1 & 0 & 2 & 2 & 0 & 2 & 2 & 3 & 1 & 2 & 0 & 0 & & 1 \\
\hline hl & 1 & 0 & 0 & 1 & 1 & & 1 & 1 & 0 & 1 & 2 & 2 & 0 & 1 & 3 & 3 & 1 & 1 & 2 & 1 & & 1 \\
\hline $\mathrm{i}$ & 5 & 0 & 1 & 1 & 4 & & 2 & 5 & 2 & 3 & 0 & 0 & 0 & 8 & 3 & 8 & 5 & 7 & 5 & 8 & 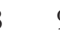 & 9 \\
\hline $\mathrm{mh}$ & 0 & 0 & 0 & 0 & 0 & & 0 & 0 & 0 & 0 & 1 & 1 & 0 & 0 & 0 & 0 & 0 & 0 & 0 & 0 & ) & 0 \\
\hline \multicolumn{23}{|l|}{ Water Quality } \\
\hline Class 1 & 0 & 0 & 0 & 0 & 0 & & 0 & 0 & 0 & 0 & 1 & 1 & 0 & 0 & 1 & 0 & 0 & 2 & 1 & 0 & ) & 1 \\
\hline Class 2 & 5 & 2 & 2 & 2 & 3 & & 2 & 4 & 0 & 2 & 5 & 5 & 0 & 7 & 8 & 6 & 4 & 8 & 4 & 5 & 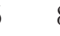 & 8 \\
\hline Class 3 & 4 & 1 & 2 & 3 & 2 & & 4 & 5 & 2 & 2 & 2 & 2 & 1 & 9 & 6 & 6 & 4 & 8 & 7 & 8 & 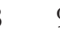 & 9 \\
\hline Class 4 & 2 & 0 & 0 & 2 & 1 & & 1 & 1 & 0 & 2 & 2 & 2 & 0 & 1 & 4 & 2 & 2 & 0 & 0 & 2 & ? & 2 \\
\hline \multicolumn{23}{|l|}{ Trophic state } \\
\hline o & 2 & 0 & 1 & 0 & 0 & & 0 & 0 & 0 & 0 & 0 & 0 & 0 & 1 & 1 & 0 & 0 & 1 & 1 & 1 & & 4 \\
\hline $\mathrm{o}-\mathrm{m}$ & 4 & 0 & 0 & 1 & 1 & & 2 & 2 & 0 & 1 & 2 & 2 & 0 & 2 & 2 & 0 & 3 & 5 & 4 & 2 & ? & 4 \\
\hline $\mathrm{m}$ & 12 & 0 & 1 & 3 & 2 & & 1 & 5 & 2 & 0 & 5 & 5 & 1 & 4 & 4 & 9 & 5 & 10 & 3 & 5 & & 6 \\
\hline me & 2 & 0 & 0 & 1 & 2 & & 1 & 1 & 2 & 2 & 3 & 3 & 0 & 2 & 4 & 6 & 4 & 1 & 0 & 2 & ? & 6 \\
\hline $\mathrm{e}$ & 2 & 0 & 0 & 1 & 1 & & 1 & 1 & 0 & 0 & 1 & 1 & 0 & 2 & 1 & 2 & 1 & 0 & 2 & 2 & ? & 1 \\
\hline
\end{tabular}

\section{Comparative floristics}

Comparative floristic methods were used for the construction of graphs for the purpose of revealing which community of studied lakes in the Artabel Lakes Nature Park are most similar. Our calculations were done on the base of algae and cyanobacteria species distribution in studied lakes (Table A1). In the first step, we take into account the species saturation in taxonomic Divisions that can give us total preferences of non-diatoms in the lakes' environment. Figure 2 shows the tree of similarity (a) and the overlapping of the species content in the lakes (b). It can be seen that on the level of less than $50 \%$ similarity, the community is strongly divided into two clusters. The first cluster (blue) included most of Artabel lakes group as well as Beş lakes and Yıldız lake 1 communities. Second, cluster (orange) combined taxa on the Divisional level in lakes Acembol group, most of Yildı group, and İsimsiz Lake. The dendrite (Fig. 2b) helps to divide studied lakes communities also into two clusters first of which included Artabel and Beş lakes and second all other.

Species-level similarity calculation (Fig. 3) show three clusters in the comparative tree. First (orange) combine communities of Acambol, Yıldız groups, and İsimsiz Lake (Fig. 3a). Second (blue) represent of Beş and Artabel 

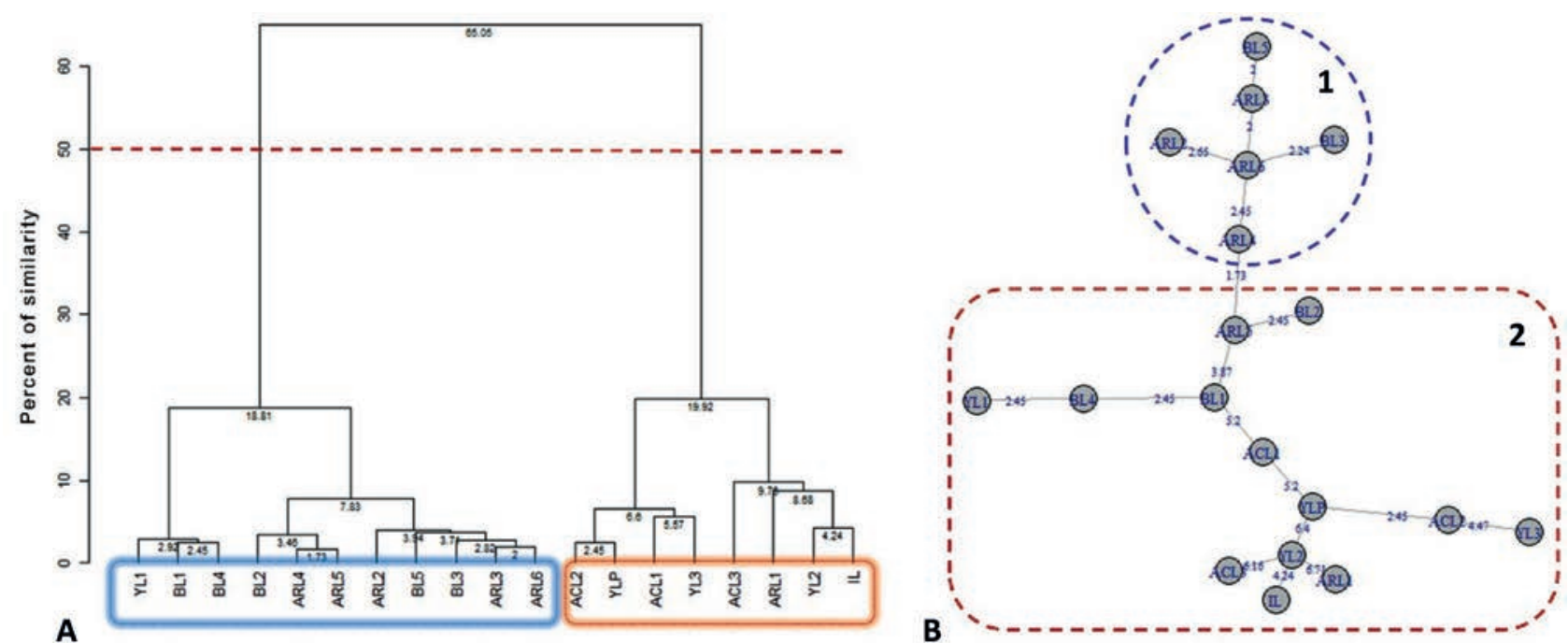

Figure 2 Comparative floristic based on Species richness in taxonomic Divisions of communities in the lakes of the Artabel Lakes Nature Park in August 2013, 2016: Tree of similarity (a); An inclusion-crossing dendrite (b)
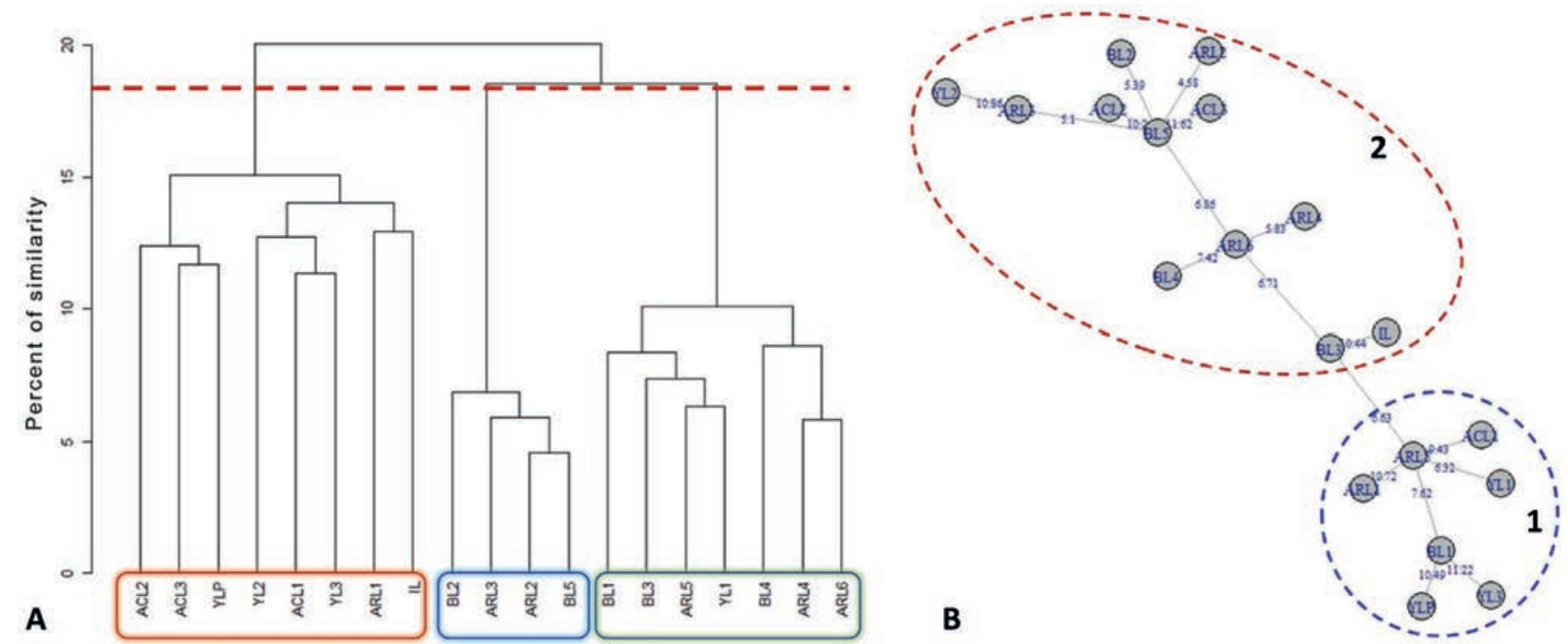

Figure 3 Comparative floristic based on total Species richness in communities of the lakes in the Artabel Lakes Nature Park in August 2013 , 2016: Tree of similarity (a); An inclusion-crossing dendrite (b)

groups, and third (green) unified communities of different groups of lakes. However, the dendrogram (Fig. 3b) divided communities of studied lakes on two cores also as in the Division level (Fig. 2b). The first core included most of the lakes of Artabel group, as well as parts from Acembol, Beş, and Yildız groups. All others are staying in core 2.

\section{Statistics}

So different combined list of lakes in Divisional and species comparison can be specified with calculation of the relationships between taxa and environmental variables in studied lakes. Therefore, CCA plot (Fig. 4) constructed on the data in Tables 1 and A1 represent the result of calculation for species richness in communities and environmental variables of the lakes of the Artabel Lakes Nature Park. All environmental variables are divided into three different groups. Reddashed round combined $\mathrm{pH}$, Conductivity and TDS, basic variables of the studied lakes. Second group (blue-dashed round) included only oxygen saturation, which depends

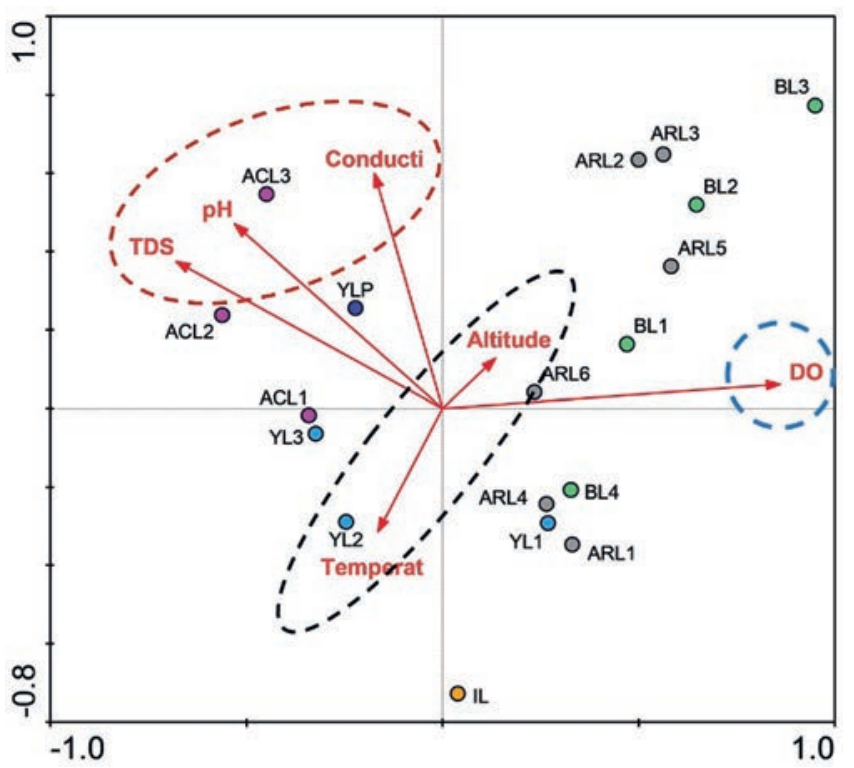

Figure 4 Canonical Correspondence Analysis (CCA) plot for species richness in communities and environmental variables of the lakes of the Artabel Lakes Nature Park in August 2013, 2016. The lakes' markers are colored in relation to the lake groups. Groups of variables are outlined by different colors 
A

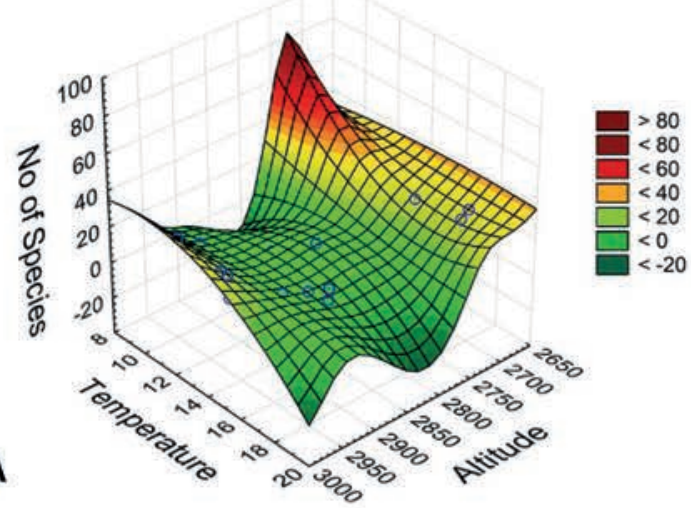

$\mathbf{E}$

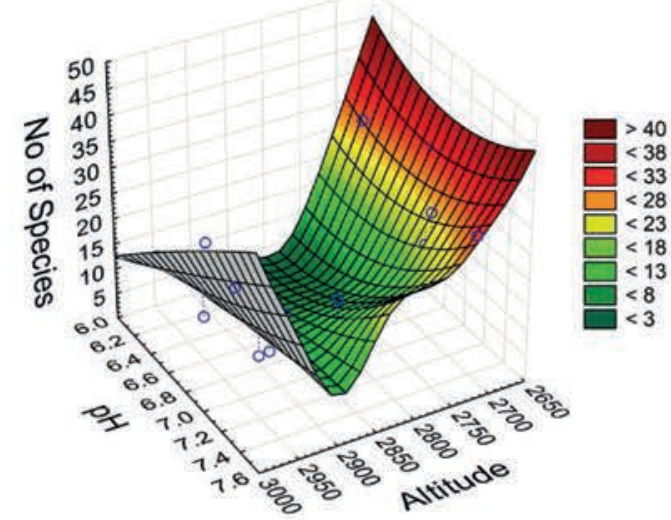

$\mathbf{E}$
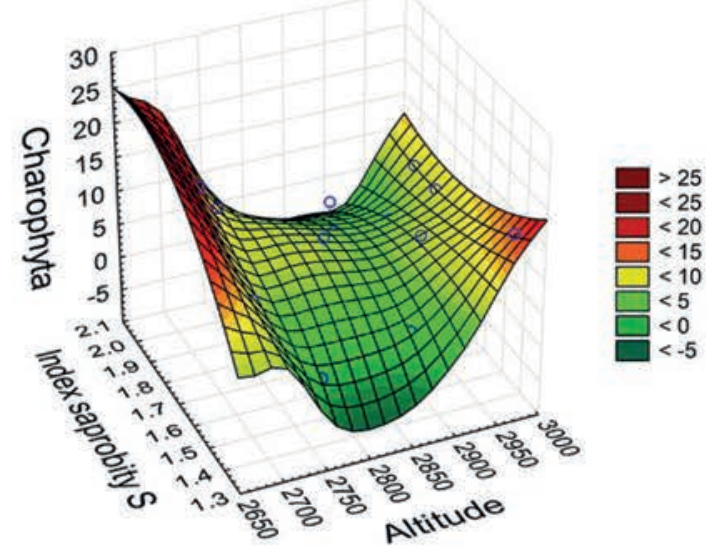

G

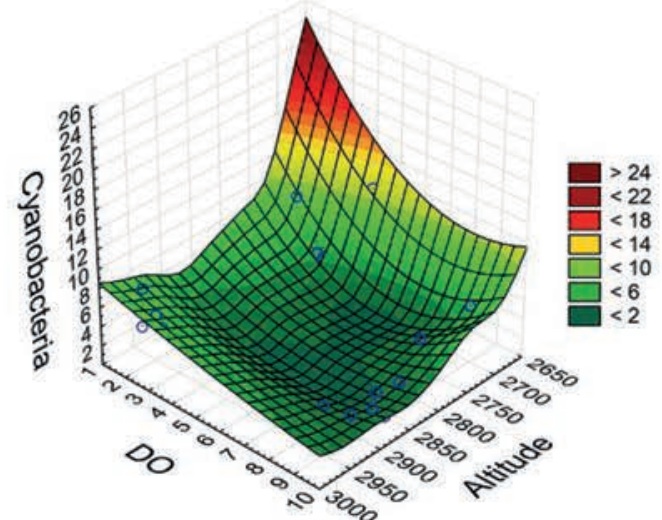

B

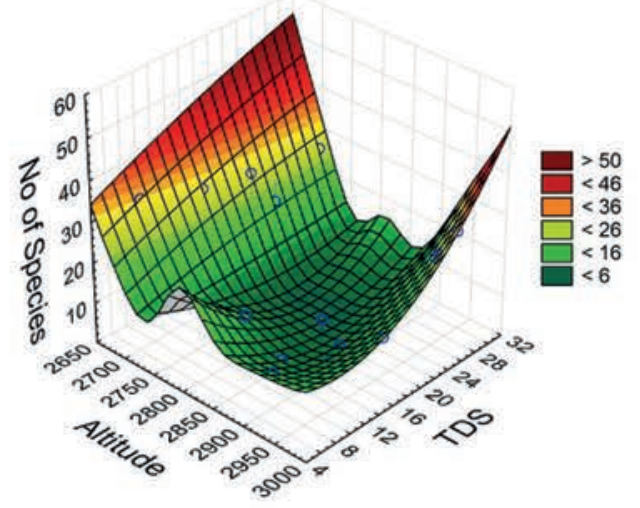

D
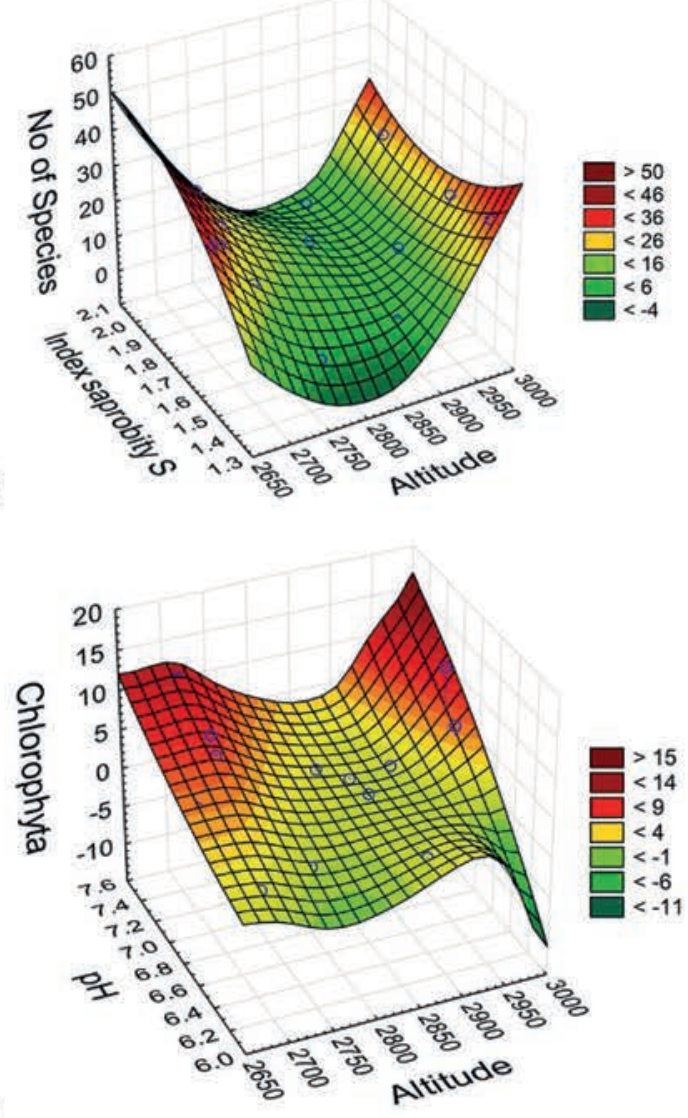

$\mathbf{F}$

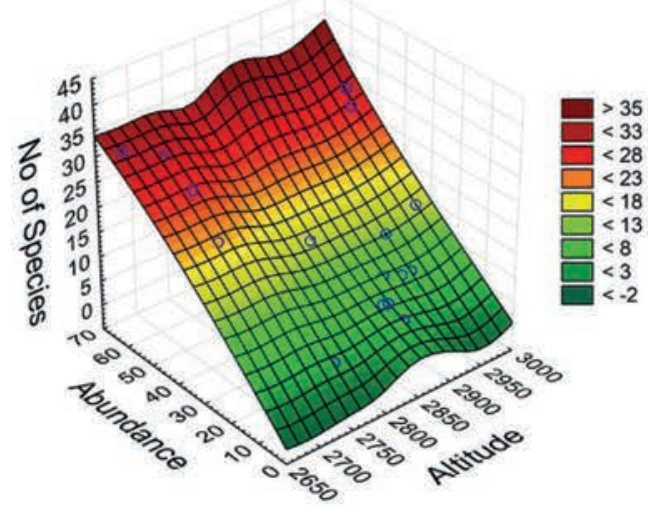

Figure 5 3D surface plots based on chemical variables and total Species richness in communities of the lakes of the Artabel Lakes Nature Park in August 2013, 2016: Species richness over altitude of the lake and water temperature (A); Species richness over altitude of the lake and water TDS (B); Species richness over altitude of the lake and water $\mathrm{pH}(\mathrm{C})$; Species richness over altitude of the lake and index saprobity SI (D); Charophyta species richness over the lake altitude and Index saprobity SI (E); Chlorophyta species richness over the lake altitude and water $\mathrm{pH}(\mathrm{F})$; Cyanobacteria species richness over the lake altitude and Dissolved oxygen $(\mathrm{G})$; Total species richness over the lake altitude and algal species abundance in the lake community $(\mathrm{H})$ 
on altitude and water temperature. Two last mentioned variables (black-dashed round) represent two mutually negatively related variables as altitude of the lake and water temperature, which decreased with altitude. In this, the first group of variables is most favorable for non-diatom communities of Acembol lakes. The oxygen saturation stays in opposite with the first group of variables and is positive for mostly Artabel and Beş groups of lakes, and Yildiz Lake 1. Altitude has positive effect for communities of most of Artabel and Bes groups of lakes but negative for Yildız Lake 2 for community of which the water temperature is important.

We tried to reveal special variables for the distribution of non-diatom communities in the Artabel Lakes Nature Park with the help of the 3D surface plots of the relationship construction. Figure 5 shows the water temperature and TDS have stimulated species richness of nondiatom algae in the studied lakes (Fig. $5 \mathrm{~A}, \mathrm{~B})$, whereas communities were species-rich in low water $\mathrm{pH}$ with high index saprobity SI (Fig. 5C, D). In any case, the distributions demonstrate two types of communities related to the altitude of the lakes. A similar distribution demonstrates the Charophyte algae (Fig. 5E) with the two-type community that species-rich in high altitude and organic enrichments. Chlorophyta species occur in high altitude lakes with high $\mathrm{pH}$ (Fig. 5F), and Cyanobacteria, on the contrary, lowermost altitude with lowest oxygen enrichments (Fig. 5G). So, the method of 3D surface construction, which we implemented earlier (Krupa et al. 2018) helps us to define that algae abundance is highest in species rich-communities and we don't reveal other factors even altitude from which abundance dependent (Fig. 5H). Therefore, this type of analysis reveals the altitude of the lakes as one of the major environmental variables which regulate the non-diatom algal community forming processes like in other high-mountain lakes in Pamir (Barinova \& Niyatbekov 2018, 2019) and Hindu Cush (Barinova et al. 2013).

\section{Bioindication}

Bioindication gives a total glance on the revealed species list in the protected area and can help to characterize the environment in which non-diatom species survived. So, Fig. 6 represents an indication of water properties of studied lakes in the Artabel Lakes Nature Park during the sampling period with the help of species-specific ecological preferences (Table 2) of revealed algae (Barinova \& Fahima 2017). In
Figure 6A can be seen as a predominance of Chlorophyta species accompanied by Cyanobacteria species richness. Algae in Artabel Park grows with benthic and planktonicbenthic lifestyle (Fig. 6B), in medium temperature (Fig. 6C), medium saturated with oxygen waters (Fig. 6D), neutral to low acidic pH (Fig. 6E), low saline (Fig. 6F) waters Class of Water Quality 2-3 (Fig. 6G). Indicators show that the studied lakes can be mesotrophic because this group of indicators strongly prevails from five groups of the trophic state (Fig. 6H). It is contrary to studied aquatic ecosystem properties in the semi-arid regions like Israel (Barinova 2011) or Kazakhstan (Jienbekov et al. 2018, 2019), where water more alkaline and saline and therefore cannot give the charophyte 
algae to survive excluding macroalgae of Chara and Nitella genera. In Artabel Park lakes prevail charophyte microalgae which prefer low saline neutral and low acidic waters with low organic pollution, therefore it can be a reference group for future monitoring of this protected area.

\section{CONCLUSION}

We studied non-diatom algae diversity in the lakes of the Artabel Lakes Nature Park for the first time. One of the important things for new natural reserve studies is the revealing of the species diversity. As a result of our first step study based on material obtained in 2013 and 2016, we revealed 154 algal species belonging to four taxonomic divisions. Charophyta algae prevail with 73 taxa mostly of the genus Cosmarium (37), then Cyanobacteria (42 taxa), Chlorophyta (30 taxa), and Euglenozoa (9 taxa). Altogether 31 taxa represent the new records for the Turkish algae flora, from which Charophyta with 25 taxa enriched mostly with genera Cosmarium (15) and Staurastrum (5). Rare species from benthic cyanobacteria were revealed in communities of the Artabel Lake 2 (ARL2).

The analysis of the distribution of algal species and their ecological preferences based on Divisional diversity and bioindication results was done for the first time for these protected lakes and show high individuality of communities. Statistical methods divided algae lists of studied lakes into two major parts: Acambol and Yıldız group, and Beş and Artabel group which belong to different streams basins.

Environmental variables such as $\mathrm{pH}$, Conductivity, and TDS are basic variables for the studied lakes and have stimulated species richness in the group of non-diatom communities of the lowermost Acembol lakes (about $2700 \mathrm{~m}$ a.s.l.). The oxygen saturation was important for Artabel and Beş groups of lakes (about $2800 \mathrm{~m}$ a.s.l.), whereas water temperature that is negatively related with altitude was important of the lake for Yildız's highest group of lakes communities (about $2900 \mathrm{~m}$ a.s.l.). Statistical analysis confirms that the altitude of the lakes is a major environmental variable that regulates the non-diatom algal community forming process in the Artabel Park.

Bioindication based on species-specific ecological preferences of revealed algae can characterize the water of studied lakes like temperate temperature, middle saturated with oxygen, neutral to low acidic $\mathrm{pH}$, low saline, Class of Water Quality 2-3, and mesotrophic.

Therefore, this assessment of the Artabel Lakes Nature Park protected lakes can serve as a reference for future investigations, which will receive new data about algal communities and environmental variables of this protected area.

\section{ACKNOWLEDGEMENTS}

This Project was financially supported by Karadeniz Technical University (BAP: FBA-2016-5487). We are grateful to teacher Vehbi Yalçin for his support in the field. This work has been partly supported by the Israeli Ministry of Aliyah and Integration.

\section{LITERAT URE CITED}

Ács, É., K. Szabo, B. Toth \& K.T. Kiss 2004. Investigation of benthic algal communities, especially diatoms of some
Hungarian streams in connection with reference conditions of the Water Framework Directives. Acta Botanica Hungarica 46: 255-277.

Akar, B. \& B. Şahin 2006. Benthic algal flora of Karanlık Lake and diversity of epipelic algae. Fresenius Environmental Bulletin 15: 48-54.

Atıc1, T. 2018. Use of cluster analyze and similarity of algae in Eastern Black Sea Region Glacier Lakes (Turkey), Key area: Artabel Lakes Natural Park. Gazi University Journal of Science 31:25-40.

Barinova, S.S., L.A. Medvedeva \& O.V. Anissimova 2006. Diversity of algal indicators in environmental assessment. Pilies Studio, Tel Aviv, 498 pp. (in Russian). [Баринова C.C., МеАведева, А.А., Анисимова, О.В. 2006. Биоазнообразие водорослей-индикаторов окружающей среды. Тель Авив: Pilies Studio. 498 c.].

Barinova, S. 2011. Algal diversity dynamics, ecological assessment and monitoring in the river ecosystems of the eastern Mediterranean. Nova Science Publishers, New York, 363 pp.

Barinova, S., N. Ali \& S.F.M. Barkatullah 2013. Ecological adaptation to altitude of algal communities in the Swat Valley (Hindu Cush Mountains, Pakistan). Expert Opinion on Environmental Biology 2:1-15.

Barinova, S. \& T. Fahima 2017. The development of the world database of freshwater algae-indicators. Journal of Environment and Ecology 8(1):1-7.

Barinova, S. \& E.G. Krupa 2017. Diversity and ecology of periphytonic algae in the Arys River Basin, Kazakhstan. Journal of Ecology and Natural Resources 1:1-14.

Barinova S. \& T. Niyatbekov 2018. Alpha-biodiversity of nondiatom algae in the Pamir aquatic habitats, Tajikistan. Biodiversity International Journal 2(3):236-363.

Barinova, S. \& T. Niyatbekov 2019. Comparative analysis of diatom algae diversity in the Pamir Protected Lakes, Tajikistan. International Journal of Advanced Research in Botany 5(2):1-17.

Barinova, S.S., O.P. Bilous \& P.M. Tsarenko 2019. Algal indication of water bodies in Ukraine: methods and prospects. Publishing House of Haifa University, Haifa, 367 pp. (in Russian). [Баринова С.С., Белоус Е.П., Царенко П.М. 2019.А^ьгоиндикация водных объектов Украины: методы и перспективы. Хайфа, Киев: ИзА-во Университета Хайфы. 367 с.].

Bellinger, E.G. \& D.C. Sigee 2010. Freshwater algae: identification and use as bioindicators. John Wiley and Sons, Chichester, 290 pp.

Borics, G., J. Padisak, I. Grigorszky, I. Oldal, L.I. Peterfi \& L. Momeu 1998. Green algal flora of the acidic bog-lake, Baláta-to SW Hungary. Biologia 53:457-465.

Bourrelly, P. \& A. Coute 1991. Desmidiées de Madagascar (Chlorophyta, Zygophyceae). J. Cramer, Stuttgart, 349 pp.

Brook, A.J. \& D.B. Williamson 2010. A monograph on some British Desmids. The Ray Society, London, 364 pp.

Coesel, P.F.M. 1984. The significance of desmids as indicators of the trophic status of freshwater. Schweizerische Zeitschrift für Hydrologie 45:388-393.

Coesel, P.F.M. 1998. Sieralgen en Natuurwaarden. Wetenschappelijke Mededelingen KNNV 224:1-56.

Coesel, P.F.M. \& K.J. Meesters 2007. Desmids of the lowlands, Mesotaeniaceae and Desmidiaceae of the European Lowlands. KNNV Publishing, Zeist, 351 pp. 
Coesel, P.F.M. \& K.J. Meesters 2013. European flora of the desmid genera Staurastrum and Staurodesmus. KNNV Publishing, Zeist, 357 pp.

Dillard, G.E. 1990. Freshwater algae of the Southeastern United States, Part 3. Chlorophyceae: Zygnematales: Zygnemataceae, Mesotaeniaceae and Desmidiaceae (Section 1). J. Cramer, Stuttgart, $172 \mathrm{pp}$.

Dillard, G.E.1991. Freshwater algae of the Southeastern United States, Part 4. Chlorophyceae: Zygnematales: Desmidiaceae (Section 2). J. Cramer, Stuttgart.

Dillard, G.E. 1993. Freshwater algae of the Southeastern United States, Part 6. Chlorophyceae: Zygnematales: Desmidiaceae (Section 4). J Cramer, Stuttgart.

Doğa Koruma Ve Milli Parklar Genel Müdürlüğü 2013. Artabel Gölleri Tabiat Parkı uzun devreli gelişme planı analitik etüt ve sentez raporu. Doğa Koruma ve Milli Parklar Genel Müdürlüğü, Ankara (in Turkish).

Feher, G. 2003. The desmid flora of some alkaline lakes and wetlands in Southern Hungary. Biologia 58:671-683.

Gábor, U. 1995. The green algal genera Scenedesmus (Chlorococcales, Chlorophyceae) with special attention to taxa occurring in Hungary. Magyar Algológiai Társaság, Budapest.

Guiry, M.D. \& G.M. Guiry 2019. AlgaeBase, world-wide electronic publication. National University of Ireland Press, Galway. Available from: http://www.algaebase.org/. Last accessed 20.06.2019.

Hindák, F. 2008. Colour atlas of cyanophytes. VEDA, Publishing House of the Slovak Academy of Sciences, Bratislava.

Huber-Pestalozzi, G. 1982. Das Phytoplankton des Süsswassers Systematik und Biologie, 8. Teil, 1. Halfte. E. Schweizerbarth'sche Verlagsbuchhandlung (Nägele u. Obermiller), Stuttgart.

Jienbekov, A, S. Barinova, A. Bigaliev, S. Nurashov, E. Sametova \& T. Fahima 2018. Bioindication using diversity and ecology of algae of the Alakol Lake, Kazakhstan. Applied Ecology and Environmental Research 16(6):7799-7831.

Jivenbekov, A, S. Barinova, A. Bigaliev, S. Nurashov, E. Sametova \& T. Fahima 2019. Ecological diversity of algae in the Alakol Lake Natural Reserve, Kazakhstan. Botanica Pacifica 8(2):63-74.

John, D.M, B.A. Whitton \& A.J. Brook 2003. The freshwater algal flora of the British Isles, an identification guide of freshwater and terrestrial algae. Cambridge University Press, Cambridge.

Kadlubowska, J.Z. 2009. Chlorophyta 8, Conjugatophyceae I: Zygnemales. In: Süßwasserflora von Mitteleuropa, Freshwater flora of Central Europe, Bd. 16 (Ettl H., Gerloff J., Heynig H., Mollenhauer D., eds), pp. 1-532. Spektrum Akademischer Verlag, Stuttgart.

Kim, Y.J. 2013. Algal flora of Korea, Chlorophyta: Chlorophyceae: Chlorococcales II: Hydrodictyaceae, Coelastraceae Vol. 6/4. National Institute of Biological Resources Ministry of Environment, Seo-gu Incheon.

Kim, H.S. 2015. Algal flora of Korea, Charophyta: Conjugatophyceae (Desmids III): Desmidiales: Desmidiaceae: Staurodesmus and Staurastrum I, Freshwater Green Algae Vol. 6/6. National Institute of Biological Resources Ministry of Environment, Seo-gu Incheon.

Kocataş, A. 1992. Ekoloji (Çevre Biyolojisi). Ege Üniversitesi Matbaas1, İzmir.

Kolaylı, S. \& B. Şahin 2009. Benthic algae (except Bacillariophyta) and their seasonal variations in Karagöl Lake (Borçka, Artvin-Turkey). Turkish Journal of Botany 33:27-32.
Komárek, J. \& K. Anagnostidis 1998. Cyanoprokaryota, 1. Teil/Part 1: Chroococcales. In: Freshwater Flora of Central Europe. Vol.19/1, (H. Ettl, J. Gerloff, H. Heynig \& D. Mollenhauer, eds), pp. 1-548. Spektrum Akademischer Verlag, Heidelberg.

Komárek, J. \& K. Anagnostidis 2005. Cyanoprokaryota: 2. Teil/Part 2: Oscillatoriales. In: Freshwater Flora of Central Europe. Vol.19/2, (B. Büdel, G. Gärtner, L. Krienitz \& M. Schagerl, eds), pp. 1-759. Spektrum Akademischer Verlag, Heidelberg.

Komárek, J. 2013. Cyanoprokaryota: 3. Teil/Part 3: Heterocytous Genera. In: Freshwater Flora of Central Europe. Vol.19/3, (B. Büdel, G. Gärtner, L. Krienitz \& M. Schagerl, eds), pp. 1-1130. Spektrum Akademischer Verlag, Heidelberg.

Krupa, E.G., S.S. Barinova, L. Ponamareva \& V.N. Tsoy 2018. Statistical mapping and 3-D surface plots in phytoplankton analysis of the Balkhash Lake (Kazakhstan). Transylvanian Review of Systematic and Ecological Research "The Wetlands Diversity" 20(1):1-16.

Lee, O.M. 2015. Additions to the six taxa of the genus Cosmarium (Desmidiaceae, Charophyta) in Korea. Journal of Ecology and Environment 38:629-636.

Lenzenweger, R. 1996, 1997, 1999. Desmidiaceenflora von Österreich Teil 1-3. J. Cramer, Stuttgart.

Lind, E.M. \& A.J. Brook 1980. Desmids of the English Lake District. Freshwater Biological Association Scientific Publication 42. The Freshwater Biological Association, Ambleside, Cumbria, 123 pp.

Novakovsky, A.B. 2004. Abilities and base principles of program module "GRAPHS." (Scientific Reports of Komi Scientific Center, Ural Division of the Russian Academy of Sciences, 27). 28 pp. (in Russian). [Новаковский А.Б. 2004. Возможности и принципы работы программного модуля "GRAPHS" (Автоматизация научных исследований. Сыктывкар, Коми научный центр УрО РАН. Вып. 27). 28 с.

Park, J.G. 2012. Algal flora of Korea, Cyanophyta: Cyanophyceae: Chroococcales, Oscillatoriales, Freshwater Cyanoprokaryota II. Vol. 5/2. National Institute of Biological Resources Ministry of Environment, Seo-gu Incheon.

Prescott, G.W. 1962. Algae of the Western Great Lakes Area. WM. C. Brown Company Publishers, Dubuque, Iowa.

Psenner, R. 2003. Alpine lakes: Extreme ecosystems under the pressures of global change. EAWAG News 55:12-15.

Round, F.E. 1953. An investigation of two benthic algal communities in Malham Tarn, Yorkshire. Journal of Ecology 41:174-197.

Ruzicka, J. 1977. Die Desmidiaceen Mitteleuropa Band 1. E. Schweizerbart'sche Verlagsbuchhandlung, Stuttgart.

Sıvacı, R.E., S. Barinova, C.N. Solak \& K. Çobanoğlu 2013. Ecological assessment of Great Lota Lake (Turkey) on the base of diatom communities. African Journal of Biotechnology 12:453-464.

Solak, C.N., S. Barinova, E. Ács \& H. Dayığlu 2012. Diversity and ecology of diatoms from Felent creek (Sakarya river basin), Turkey. Turkish Journal of Botany 36:191-203.

Sládečková, A. 1962. Limnological investigation methods for the periphyton ("Aufwuchs") community. Botanical Review 28:286-350.

Štastný, J. 2010. Desmids (Conjugatophyceae, Viridiplantae) from the Czech Republic; new and rare taxa, distribution, ecology. Fottea 10:1-74. 
Stevenson, J. 2014. Ecological assessments with algae: a review and synthesis. Journal of Phycology 50:437-461.

Şahin, B. 1998. Some new records of desmids from Turkey. Pakistan Journal of Botany 30:7-13.

Şahin, B. 2000. Some new desmids records for the freshwater algal flora of Turkey. Flora Mediterranea 10:223-226.

Şahin, B. 2001. Epipelic and epilithic algae of Dağbaşı Lale (Rize-Turkey). Turkish Journal of Botany 25:187-194.

Şahin, B. 2002. Contribution to the desmid flora of Turkey. Algological Studies 107:39-48.

Şahin, B. 2003. Biodiversity of benthic algal communities in some high mountain lakes of the Turkish Eastern Black Sea Region. Cryptogamie, Algologie 24:341-353.

Şahin, B. 2004. Species composition and diversity of epipelic algae in Çatal Lake (Şebinkarahisar-Giresun, Turkey). Turkish Journal of Biology 28:103-109.

Şahin, B. 2008. Species composition and diversity of epipelic algae in Limni Lake (Gümüşhane, Turkey). Acta Botanica Hungarica 50:397-405.

Şahin, B. 2019. Charophyta. In: Türkiye Suyosunlar Listesi (Turkey list of algae), (E. Taşkın, ed.), pp. 181-223. Ali Nihat Gökyiğit Vakfı Yayını, İstanbul.

Şahin, B. \& B. Akar 2005. Epipelic and epilithic algae of Küçükgöl Lake (Gümüşhane-Turkey). Turkish Journal of Biology 29:57-63.
Şahin, B., B. Akar \& İ. Bahçeci 2010. Species composition and diversity of epipelic algae in Balık Lake (Şavşat-Artvin, Turkey). Turkish Journal of Botany 34:441-448.

Şahin, B. \& B. Akar 2019a. New desmid records from high mountain lakes in Artabel Lakes Nature Park, Gümüşhane, Turkey. Turkish Journal of Botany 43:570-583.

Şahin, B. \& B. Akar 2019b. New records from Artabel Lakes Nature Park (Gümüşhane/Turkey) to the freshwater algal flora of Turkey. Turkish Journal of Botany 43:135-142.

Taşkın, E. (ed.) 2019. Türkiye Suyosunlar Listesi (Turkey List of algae). Ali Nihat Gökyiğit Vakfı Yayını, İstanbul.

ter Braak, C.J.F. \& P. Šmilauer 2002. CANOCO Reference Manual and CanoDraw for W indows User's Guide: Software for Canonical Community Ordination (version 4.5). Ithaca. Microcomputer Power Press.

Vitonyte, I. \& J. Kasperovičienè 2015. Phytobenthos cyanobacteria species new to Lithuanian rivers. Botanica Lithuanica 21:99-118.

West, W. \& G.S. West 1904, 1905, 1908, 1912, 1923. A monograph of the British Desmidiaceae, vol. 1-5. The Ray Society, London.

Wotowski, K. \& F. Hindak 2005. Atlas of Euglenophytes. VEDA, Publishing House of the Slovak Academy of Sciences, Bratislava. 
Table A1. List of the non-diatom taxa of the studied lakes of the Artabel Lakes Nature Park, Turkey in August 2013, 2016 with species-specific ecological properties and index saprobity SI. Abbreviation of the lakes name: ARL: Artabel Lakes, BL: Bes Lakes, YL: Yıldız Lakes, ACL: Acembol Lakes, IL: İsimsiz Lake, YLP: Yıldız Lakes Pond; *: new record for algal flora of Turkey. Abbreviation of the ecological groups of indicators (Barinova et al. 2006): Habitat preferences (Hab): P - planktonic, P-B - planktonic-benthic, B - benthic, wide range, need some substrate; Ep - epiphytes. Water temperature preferences $(\mathrm{T})$ : warm - warm-water inhabitants; temp - temperate water temperature inhabitants or indifferent; eterm eurythermic. Oxygenation indicators (Oxy): st - standing water, st-str - low streaming water, aer - aerophiles. Salinity (Sal): hb - oligohalobes-halophobes, $\mathrm{i}$ - oligohalobes-indifferents, $\mathrm{mh}$ - mesohalobes, hl - halophiles. Acidity $(\mathrm{pH})$ degree indicators $(\mathrm{pH})$ : alf - alkaliphiles, ind - indifferents; acf - acidophiles. Trophic state indicators (Tro): o - oligotraphentic; o-m - oligomesotraphentic; $\mathrm{m}$ - mesotraphentic; me - meso-eutraphentic; e - eutraphentic. SI: species-specific index saprobity SI.

\begin{tabular}{|c|c|c|c|c|c|c|c|c|c|}
\hline \multirow[b]{2}{*}{ Taxa } & Lake & \multicolumn{8}{|c|}{ Ecological parameter } \\
\hline & 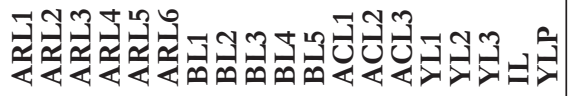 & Hab & $\mathbf{T}$ & Oxy & $\mathrm{pH}$ & Sal & Sap & Tro & SI \\
\hline CHAROP & & & & & & & & & \\
\hline $\begin{array}{l}\text { Actinotaenium cucurbita (Brébisson ex Ralfs) } \\
\text { Teiling }\end{array}$ & $\begin{array}{lllllllllllllllllll}0 & 0 & 0 & 0 & 0 & 0 & 0 & 0 & 0 & 0 & 0 & 0 & 0 & 0 & 0 & 2 & 0 & 0 & 2\end{array}$ & P-B & - & aer & acf & - & $x-b$ & $\mathrm{o}$ & 0.9 \\
\hline $\begin{array}{l}\text { *Actinotaenium curtum (Brébisson ex Ralfs) } \\
\text { Teiling ex Rúžicka \& Pouzar }\end{array}$ & $\begin{array}{lllllllllllllllllll}0 & 0 & 0 & 0 & 0 & 0 & 0 & 0 & 0 & 0 & 0 & 0 & 0 & 0 & 0 & 0 & 0 & 2 & 0\end{array}$ & P-B & - & aer & ind & - & $x-b$ & $\mathrm{o}-\mathrm{m}$ & 0.9 \\
\hline Closterium acerosum Ehrenberg ex Ralfs & 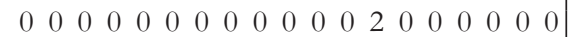 & P-B & - & st-str & ind & $\mathrm{i}$ & $\mathrm{a}-\mathrm{O}$ & $\mathrm{e}$ & 2.6 \\
\hline *Closterium cornu Ehre & $\begin{array}{llllllllllllllllllll}0 & 0 & 0 & 0 & 0 & 0 & 0 & 0 & 0 & 0 & 0 & 0 & 0 & 0 & 0 & 0 & 2 & 0 & 0\end{array}$ & B & & aer & acf & - & $x-b$ & $\mathrm{o}-\mathrm{m}$ & 0.95 \\
\hline Closterium incurvum Brébisson & $\begin{array}{lllllllllllllllllll}0 & 0 & 0 & 0 & 0 & 0 & 0 & 0 & 0 & 2 & 0 & 0 & 0 & 0 & 0 & 0 & 0 & 2 & 0\end{array}$ & B & & - & ind & - & $\mathrm{O}-\mathrm{a}$ & me & 1.8 \\
\hline $\begin{array}{l}\text { Closterium jenneri var. cynthia (De Notaris) } \\
\text { Petlovany }\end{array}$ & $\begin{array}{lllllllllllllllllll}0 & 0 & 0 & 0 & 0 & 0 & 0 & 0 & 0 & 0 & 0 & 0 & 0 & 0 & 0 & 2 & 0 & 0 & 0\end{array}$ & P-B & - & st-str & acf & - & o & $\mathrm{m}$ & 1 \\
\hline $\begin{array}{l}\text { Closterium lunula Ehrenberg \& Hemprich } \\
\text { ex Ralfs }\end{array}$ & $\begin{array}{lllllllllllllllllll}0 & 0 & 0 & 2 & 0 & 0 & 0 & 0 & 0 & 0 & 0 & 2 & 0 & 0 & 0 & 2 & 0 & 0 & 0\end{array}$ & $\mathrm{~B}$ & - & - & ind & - & $\mathrm{x}-\mathrm{b}$ & $\mathrm{m}$ & 0.8 \\
\hline Im parvulum Nägeli & $\begin{array}{llllllllllllllllllll}0 & 0 & 0 & 0 & 0 & 0 & 0 & 0 & 0 & 0 & 0 & 0 & 0 & 0 & 0 & 2 & 0 & 0 & 0\end{array}$ & P-B & - & - & ind & $\mathrm{i}$ & $\mathrm{b}$ & $\mathrm{m}$ & 2 \\
\hline Closterin & $\begin{array}{llllllllllllllllllll}0 & 0 & 0 & 0 & 0 & 0 & 0 & 0 & 0 & 0 & 0 & 0 & 0 & 0 & 0 & 0 & 2 & 0 & 0\end{array}$ & P-B & - & st-str & ind & - & $\mathrm{o}-\mathrm{a}$ & e & 1.9 \\
\hline *Cosma & $\begin{array}{llllllllllllllllllll}0 & 0 & 0 & 0 & 0 & 0 & 0 & 0 & 0 & 0 & 0 & 0 & 0 & 0 & 0 & 2 & 0 & 0 & 0\end{array}$ & B,aer & - & aer & acf & - & - & $\mathrm{m}$ & - \\
\hline *Cosmarium boitierense Kouwets & $\begin{array}{llllllllllllllllllll}0 & 0 & 0 & 0 & 0 & 0 & 0 & 0 & 0 & 2 & 0 & 0 & 0 & 0 & 0 & 0 & 0 & 0 & 0\end{array}$ & B & - & - & ind & - & - & me & - \\
\hline m botrytis Meneghini ex Ralfs var. & $\begin{array}{lllllllllllllllllll}0 & 0 & 0 & 0 & 0 & 0 & 0 & 1 & 0 & 0 & 0 & 0 & 0 & 1 & 0 & 1 & 1 & 0 & 1\end{array}$ & P-B & - & st-str & ind & $\mathrm{i}$ & $\mathrm{o}-\mathrm{a}$ & $\mathrm{m}$ & 1.9 \\
\hline $\begin{array}{l}\text { m botrytis var. gemmiferum } \\
\text { son) Nordstedt }\end{array}$ & $\begin{array}{lllllllllllllllllll}0 & 0 & 0 & 0 & 0 & 0 & 0 & 0 & 0 & 0 & 0 & 0 & 0 & 0 & 2 & 2 & 0 & 0 & 0\end{array}$ & B & - & - & ind & - & - & $\mathrm{m}$ & - \\
\hline Cosmarium botrytis var. $t$ & $\begin{array}{llllllllllllllllllll}0 & 0 & 0 & 0 & 0 & 0 & 0 & 0 & 0 & 0 & 0 & 0 & 0 & 2 & 2 & 0 & 0 & 0 & 0\end{array}$ & P-B & & - & ind & - & $\mathrm{O}-\mathrm{a}$ & $\mathrm{m}$ & 1.9 \\
\hline Coesel & $\begin{array}{lllllllllllllllllll}2 & 0 & 2 & 0 & 0 & 0 & 0 & 0 & 0 & 0 & 0 & 0 & 0 & 0 & 0 & 0 & 0 & 0 & 0\end{array}$ & B & & - & acf & - & - & $\mathrm{m}$ & - \\
\hline Corda ex Ralfs & $\begin{array}{llllllllllllllllllll}0 & 0 & 0 & 0 & 0 & 0 & 0 & 0 & 0 & 0 & 0 & 0 & 0 & 0 & 0 & 2 & 0 & 0 & 0\end{array}$ & $\mathrm{~B}$ & - & - & acf & - & - & $\mathrm{m}$ & - \\
\hline Cosm & $\begin{array}{llllllllllllllllllll}0 & 0 & 0 & 0 & 0 & 0 & 0 & 0 & 0 & 0 & 0 & 0 & 0 & 0 & 0 & 2 & 0 & 0 & 0\end{array}$ & B & & aer & & - & - & $\mathrm{m}$ & - \\
\hline $\begin{array}{l}\text { *Cosmarium bolmiense var. bibernicum (West) } \\
\text { Schmidle }\end{array}$ & $\begin{array}{llllllllllllllllllll}0 & 0 & 0 & 0 & 0 & 0 & 0 & 0 & 0 & 0 & 0 & 0 & 0 & 0 & 0 & 2 & 0 & 0 & 0\end{array}$ & B,aer & - & aer & acf & - & - & $\mathrm{m}$ & - \\
\hline impressulum Elfving var. & $\begin{array}{lllllllllllllllllll}1 & 0 & 0 & 0 & 0 & 0 & 1 & 0 & 0 & 0 & 1 & 1 & 0 & 0 & 0 & 0 & 0 & 0 & 0\end{array}$ & $\mathrm{~B}$ & - & - & ind & $\mathrm{hb}$ & b-o & $\mathrm{m}$ & 1.6 \\
\hline $\begin{array}{l}\text { * Cosmarium impressulum var. alpicola } \\
\text { Schmidle }\end{array}$ & 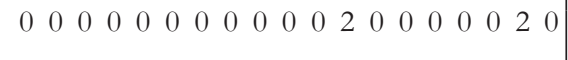 & B & - & - & acf & - & b-o & $\mathrm{m}$ & 1.6 \\
\hline Cosmarium laeve Rabenhorst & $\begin{array}{llllllllllllllllllll}0 & 0 & 0 & 0 & 0 & 0 & 0 & 1 & 0 & 0 & 0 & 1 & 1 & 1 & 0 & 1 & 0 & 1 & 0\end{array}$ & P-B & - & st-str & ind & $\mathrm{hb}$ & $\mathrm{o}-\mathrm{a}$ & me & 1.9 \\
\hline $\begin{array}{l}\text { Cosmarium margaritatum (P.lundell) J.Roy \& } \\
\text { Bisset }\end{array}$ & $\begin{array}{lllllllllllllllllll}0 & 0 & 0 & 0 & 0 & 0 & 0 & 0 & 0 & 0 & 0 & 0 & 0 & 2 & 0 & 0 & 0 & 0 & 0\end{array}$ & B & - & - & acf & - & - & $\mathrm{m}$ & - \\
\hline $\begin{array}{l}\text { *Cosmarium norimberrense var. depressum (West \& } \\
\text { G.S.West) Willi Krteger \& Gerloff }\end{array}$ & $\begin{array}{lllllllllllllllllll}2 & 0 & 0 & 0 & 0 & 0 & 0 & 0 & 0 & 0 & 0 & 0 & 2 & 0 & 0 & 0 & 0 & 0 & 0\end{array}$ & B & - & - & ind & - & - & $\mathrm{m}$ & - \\
\hline $\begin{array}{l}\text { *Cosmarium notabile var. subnotabile (Wille) } \\
\text { Coesel }\end{array}$ & 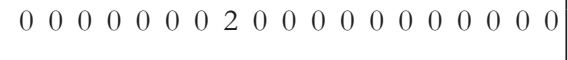 & B,aer & - & - & - & - & - & $\mathrm{m}$ & - \\
\hline $\begin{array}{l}\text { Cosmarium notabile var. transiens Insam \& } \\
\text { Willi Krieger }\end{array}$ & 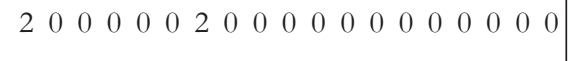 & B,aer & - & - & acf & - & - & $\mathrm{m}$ & - \\
\hline usatum (Schmidle) Schmidle & $\begin{array}{llllllllllllllllllll}2 & 0 & 0 & 0 & 2 & 0 & 0 & 0 & 0 & 0 & 0 & 0 & 0 & 0 & 0 & 0 & 0 & 0 & 0\end{array}$ & B & & - & ind & $\mathrm{i}$ & $\mathrm{o}$ & me & 1.3 \\
\hline atiodes var. dicken & $\begin{array}{lllllll}0 & 0 & 0 & 0 & 0 & 0 & 0\end{array}$ & B & - & - & acf & - & - & $\mathrm{m}$ & - \\
\hline $\begin{array}{l}\text { *Cosmarium pokornyanum (Grunow) West } \\
\& \text { G.S.West }\end{array}$ & 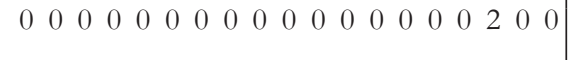 & B,aer & - & aer & acf & $\mathrm{hl}$ & - & $\mathrm{m}$ & - \\
\hline $\begin{array}{l}\text { *Cosmarium polygonum var. hexagonum } \\
\text { Grönblad }\end{array}$ & 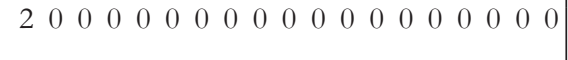 & B & - & - & acf & - & - & o & - \\
\hline *Cosm & $\begin{array}{lllllllllllllllll}2 & 0 & 0 & 0 & 0 & 0 & 0 & 0 & 0 & 0 & 0 & 0 & 0 & 0 & 0 & 0\end{array}$ & & & - & & - & & $\mathrm{m}$ & \\
\hline $\begin{array}{l}\text { *Cosmarium pseudoornatum B.Eichler \& } \\
\text { Gutwinsk1 }\end{array}$ & & B & - & - & acf & - & - & $\mathrm{m}$ & - \\
\hline Cosmari & $\begin{array}{llllllllllllllllllll}0 & 0 & 0 & 0 & 0 & 0 & 2 & 0 & 0 & 0 & 0 & 0 & 0 & 0 & 0 & 0 & 0 & 0 & 0\end{array}$ & P-B & & - & & $\mathrm{hb}$ & c & & 1.3 \\
\hline Cosma & $\begin{array}{lllllllllllllllllll}1 & 0 & 0 & 0 & 0 & 0 & 0 & 1 & 0 & 0 & 0 & 0 & 0 & 1 & 0 & 0 & 0 & 1 & 0\end{array}$ & B & & - & & - & - & me & - \\
\hline $\begin{array}{l}\text { Cosmarium regnellii var. minimum Eichler \& } \\
\text { Gutwinski }\end{array}$ & $\begin{array}{llllllllllllllllllll}0 & 0 & 0 & 0 & 0 & 0 & 0 & 0 & 0 & 0 & 0 & 0 & 0 & 2 & 0 & 0 & 0 & 0 & 0\end{array}$ & B & - & - & acf & - & - & $\mathrm{m}$ & - \\
\hline $\begin{array}{l}\text { Im regnellii var. psendoregnellii } \\
\text { kommer) Willi Krieger }\end{array}$ & $\begin{array}{llllllllllllllllllll}0 & 0 & 0 & 0 & 0 & 0 & 0 & 0 & 0 & 0 & 0 & 0 & 0 & 0 & 0 & 0 & 0 & 2 & 0\end{array}$ & B & - & - & acf & - & - & $\mathrm{m}$ & - \\
\hline Cosmarium reniforme (Ralfs) W.Archer & $\begin{array}{llllllllllllllllllll}0 & 0 & 0 & 0 & 0 & 0 & 0 & 0 & 0 & 0 & 0 & 0 & 2 & 2 & 0 & 0 & 0 & 0 & 0\end{array}$ & & - & st-str & & $\mathrm{hb}$ & $\mathrm{o}$ & me & 1.0 \\
\hline $\begin{array}{l}\text { *Cosmarium reniforme var. compressum } \\
\text { Nordstedt }\end{array}$ & & P-B & - & & ind & $\mathrm{hb}$ & o & me & 1.0 \\
\hline $\begin{array}{l}\text { *Cosmarium simplicius (West \& G.S.West) } \\
\text { Grönblad }\end{array}$ & 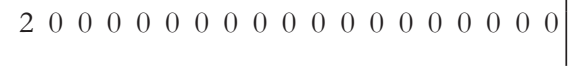 & B,aer & - & aer & acf & - & - & $\mathrm{m}$ & - \\
\hline Cosmar & $\begin{array}{lllllllllllllllllll}0 & 0 & 0 & 0 & 0 & 0 & 0 & 0 & 0 & 0 & 0 & 0 & 0 & 2 & 0 & 0 & 0 & 0 & 0\end{array}$ & & & - & & & & e & \\
\hline$m$ & $\begin{array}{llllllllllllllllll}3 & 0 & 0 & 0 & 3 & 0 & 3 & 0 & 0 & 0 & 0 & 3 & 0 & 3 & 3 & 0 & 3 & 3\end{array}$ & P-B & - & - & ind & i & - & e & - \\
\hline $\begin{array}{l}\text { Cosmarium subcostatum var. minus (West \& } \\
\text { G.S.West) Kurt Föster }\end{array}$ & 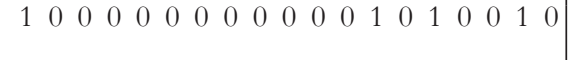 & $\mathrm{B}$ & - & - & ind & - & - & $\mathrm{m}$ & - \\
\hline Cosmarium subcrenatum Hantzsch & $\begin{array}{lllllllllllllllllll}0 & 0 & 0 & 0 & 1 & 0 & 0 & 0 & 0 & 1 & 0 & 0 & 0 & 0 & 1 & 0 & 0 & 0 & 1\end{array}$ & B,aer & - & aer & acf & - & $\mathrm{o}$ & $\mathrm{m}$ & 1.1 \\
\hline
\end{tabular}


$\underline{\text { Table A1. Continued }}$

Taxa

\section{*Cosmarium subspeciosum var. transiens} Messikommer

Cosmarium tinctum Ralfs

Cosmarium turpinii Brébisson

Cosmarium vogesiacum var. alpinum (Schmidle) Laporte

Cylindrocystis brebissonii (Ralfs) De Bary Euastrum bidentatum Nägeli

Euastrum binale var. gutwinskii (Schmidle) Homfeld

Euastrum oblongum Ralfs

Gonatozygon monotaenium De Bary

Klebsormidium klebsii (G.M.Smith) P.C.Silva,

K.R.Mattox \& W.H.Blackwell

Micrasterias americana Ehrenberg ex Ralfs

* Micrasterias truncata Brébisson ex Ralfs

Netrium digitus (Brébisson ex Ralfs)

Itzigsohn \& Rothe

Penium margaritaceum Brébisson

Spirogyra oligocarpa C.-C.Jao

Spirogyra tenuissima (Hassall) Kützing

* Spondylosium papillosum West \& G.S.West

Staurastrum bieneanum Rabenhorst

Staurastrum boreale West \& G.S.West

* Staurastrum dilatatum Ehrenberg ex Ralfs

Staurastrum dispar Brébisson

* Staurastrum dybowskii Woloszynska

*Staurastrum lapponicum (Schmidle)

Grönblad

Staurastrum pilosum Brébisson

Staurastrum punctulatum Brébisson

* Staurastrum punctulatum var. pygmaeum (Brébisson ex Ralfs) West \& G.S.West

*Teilingia excavata var. subquadrata (West \&
G.S.West ex N.Carter) Stein

Teilingia granulata (J.Roy \& Bisset)

Bourrelly

*Tetmemorus laevis Ralfs ex Ralfs

Zygnema pseudocylindricum Gauthier-Lièvre

\section{CYANOBACTERIA}

Ammatoidea normanii West \& G.S.West

Aphanocapsa incerta (Lemmermann)

G.Cronberg \& Komárek

Calothrix braunii Bornet \& Flahault

Calothrix fusca Bornet \& Flahault f. fusca

Calothrix fusca f. parva (Ercegovic)

Poljansky

Chroococcus dispersus (Keissler)

Lemmermann

Chroococcus minutus (Kützing) Nägeli

Chroococcus spelaeus Ercegovic

Chroococcus subnudus (Hansgirg)

G.Cronberg \& J.Komárek

Chroococcus turgidus (Kützing) Nägeli

Cyanosarcina parthenonensis Anagnostidis

Cyanothece aeruginosa (Nägeli) Komárek

Glaucospira laxissima (G.S.West) Simic,

Komárek \& Dordevic

* Katagnymene accurata Geitler

Komvophoron crassum (Vozzhennikova)

Anagnostidis \& Komárek

Lyngbya aestuarii Liebman ex Gomont

Merismopedia elegans A.Braun ex Kützing

Merismopedia glauca (Ehrenberg) Kützing

Merismopedia messikommeri Joosten

Merismopedia minima G.Beck

Merismopedia punctata Meyen

Microcoleus amoenus (Gomont) Strunecky,

Komárek \& J.R.Johansen

Microcoleus autumnalis (Gomont) Struneck

Komárek \& J.R.Johansen

Nostoc sp. 1

Nostoc sp. 2

Oscillatoria anguina Bory ex Gomont

Oscillatoria limosa C.Agardh ex Gomont

Oscillatoria ornata Kützing ex Gomont

Oscillatoria simplicissima Gomont Ecological parameter

Lake

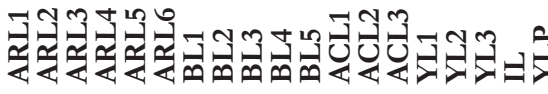

Hab T Oxy pH Sal Sap Tro SI

$\begin{array}{llllllllllllllllllll}0 & 0 & 0 & 0 & 0 & 0 & 0 & 0 & 0 & 0 & 0 & 0 & 1 & 0 & 0 & 1 & 1 & 0 & 1\end{array}$

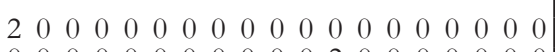

$\begin{array}{llllllllllllllllllll}0 & 0 & 0 & 0 & 0 & 0 & 0 & 0 & 0 & 0 & 0 & 2 & 0 & 0 & 0 & 0 & 0 & 0 & 0 & \text { P-B }\end{array}$

$\begin{array}{lllllllllllllllllll}0 & 0 & 0 & 0 & 0 & 0 & 0 & 0 & 0 & 2 & 0 & 0 & 0 & 2 & 0 & 0 & 0 & 0 & 0\end{array}$

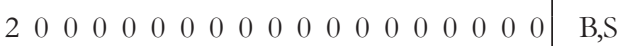

$\begin{array}{llllllllllllllllllll}2 & 0 & 0 & 0 & 0 & 0 & 0 & 0 & 0 & 0 & 0 & 0 & 0 & 0 & 0 & 0 & 0 & 0 & 0 & \text { P-B }\end{array}$

\begin{tabular}{lllllllllllllllllll}
0 & 0 & 2 & 0 & 0 & 0 & 0 & 0 & 0 & 0 & 0 & 0 & 0 & 0 & 0 & 0 & 0 & 0 & 0 \\
\hline
\end{tabular}

$\begin{array}{lllllllllllllllllll}0 & 0 & 0 & 0 & 0 & 0 & 2 & 0 & 0 & 2 & 0 & 0 & 0 & 0 & 0 & 0 & 0 & 0 & 0 \\ 0 & 0 & 0 & 0 & 0 & 0 & 0 & 0 & 0 & 0 & 0 & 0 & 0 & 0 & 2 & 0 & 0 & 0 & 0\end{array}$

$\begin{array}{lllllllllllllllllll}0 & 0 & 0 & 0 & 0 & 0 & 0 & 0 & 0 & 0 & 0 & 0 & 0 & 0 & 2 & 0 & 0 & 0 & 0\end{array}$

$\begin{array}{lllllllllllllllllll}0 & 0 & 0 & 0 & 0 & 0 & 0 & 0 & 0 & 0 & 0 & 0 & 0 & 0 & 0 & 0 & 0 & 0 & 2\end{array}$

$\begin{array}{lllllllllllllllllll}0 & 0 & 0 & 0 & 0 & 0 & 0 & 0 & 0 & 0 & 0 & 0 & 0 & 0 & 0 & 0 & 0 & 2 & 0\end{array}$

$\begin{array}{lllllllllllllllllll}0 & 0 & 0 & 0 & 0 & 0 & 0 & 0 & 0 & 0 & 0 & 0 & 0 & 0 & 0 & 2 & 0 & 0 & 0\end{array}$

$\begin{array}{lllllllllllllllllll}0 & 0 & 0 & 0 & 0 & 0 & 0 & 0 & 0 & 0 & 0 & 0 & 0 & 0 & 0 & 2 & 0 & 0 & 0\end{array}$

$\begin{array}{lllllllllllllllllll}0 & 0 & 0 & 0 & 0 & 0 & 0 & 0 & 0 & 2 & 0 & 0 & 2 & 0 & 0 & 0 & 0 & 2 & 0\end{array}$

$\begin{array}{lllllllllllllllllll}0 & 0 & 0 & 0 & 0 & 0 & 2 & 0 & 0 & 0 & 0 & 0 & 0 & 0 & 0 & 0 & 0 & 0 & 2\end{array}$

$\begin{array}{lllllllllllllllllll}0 & 0 & 0 & 0 & 0 & 0 & 0 & 0 & 0 & 0 & 0 & 0 & 0 & 0 & 0 & 0 & 0 & 2 & 0\end{array}$

$\begin{array}{lllllllllllllllllll}2 & 0 & 0 & 0 & 0 & 0 & 0 & 0 & 0 & 0 & 0 & 0 & 0 & 0 & 0 & 0 & 0 & 0 & 0\end{array}$

$\begin{array}{lllllllllllllllllll}0 & 0 & 0 & 0 & 0 & 0 & 0 & 0 & 0 & 0 & 0 & 0 & 0 & 2 & 0 & 0 & 0 & 0 & 0\end{array}$

$\begin{array}{lllllllllllllllllll}0 & 0 & 0 & 2 & 0 & 0 & 0 & 0 & 0 & 0 & 0 & 0 & 0 & 0 & 0 & 0 & 0 & 0 & 0\end{array}$

$\begin{array}{lllllllllllllllllll}0 & 0 & 0 & 0 & 0 & 0 & 0 & 0 & 0 & 0 & 0 & 0 & 0 & 0 & 2 & 0 & 0 & 2 & 0 \\ 0 & 0 & 0 & 0 & 0 & 1 & 1 & 0 & 0 & 1 & 0 & 0 & 1 & 1 & 1 & 0 & 0 & 1 & 0\end{array}$

$\begin{array}{llllllllllllllllllll}0 & 0 & 0 & 0 & 0 & 1 & 1 & 0 & 0 & 1 & 0 & 0 & 1 & 1 & 1 & 0 & 0 & 1 & 0\end{array}$

$\begin{array}{lllllllllllllllllll}0 & 0 & 0 & 2 & 0 & 0 & 0 & 0 & 0 & 0 & 0 & 0 & 0 & 0 & 0 & 0 & 0 & 0 & 0\end{array}$

$\begin{array}{lllllllllllllllllll}0 & 0 & 0 & 0 & 0 & 0 & 0 & 0 & 0 & 0 & 0 & 0 & 0 & 2 & 0 & 0 & 0 & 2 & 2\end{array}$

$\begin{array}{llllllllllllllllllll}0 & 0 & 0 & 0 & 0 & 0 & 0 & 0 & 0 & 0 & 0 & 2 & 0 & 0 & 0 & 0 & 0 & 0 & 0 & \text { P-B }\end{array}$

\begin{tabular}{lllllllllllllllllll}
4 & 0 & 0 & 4 & 4 & 4 & 4 & 0 & 4 & 4 & 0 & 4 & 0 & 0 & 4 & 0 & 4 & 4 & 0 \\
\hline
\end{tabular}

$\begin{array}{llllllllllllllllllll}0 & 0 & 0 & 0 & 0 & 0 & 0 & 0 & 0 & 0 & 0 & 0 & 0 & 0 & 0 & 0 & 2 & 0 & 0 & B \\ \text {, aer }\end{array}$

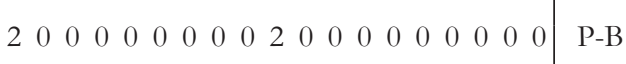

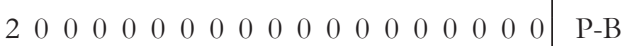

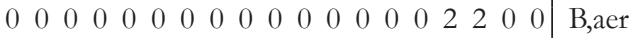

$\begin{array}{lllllllllllllllllllll}0 & 0 & 0 & 0 & 0 & 0 & 0 & 2 & 0 & 0 & 0 & 0 & 0 & 0 & 0 & 0 & 0 & 0 & 0\end{array}$

$2 \begin{array}{lllllllllllllllllll}2 & 2 & 0 & 0 & 0 & 0 & 0 & 2 & 0 & 0 & 0 & 0 & 0 & 0 & 0 & 0 & 0 & 0 & 0\end{array}$ $\begin{array}{lllllllllllllllllll}0 & 0 & 0 & 0 & 0 & 0 & 0 & 0 & 0 & 0 & 0 & 0 & 0 & 2 & 2 & 0 & 0 & 0 & 0\end{array}$

$\begin{array}{lllllllllllllllllll}0 & 0 & 0 & 0 & 0 & 0 & 0 & 0 & 0 & 0 & 0 & 0 & 0 & 0 & 0 & 0 & 0 & 2 & 0\end{array}$

$\begin{array}{lllllllllllllllllll}0 & 0 & 0 & 0 & 0 & 0 & 0 & 0 & 0 & 0 & 0 & 2 & 2 & 0 & 0 & 0 & 0 & 2 & 0\end{array}$

$\begin{array}{lllllllllllllllllll}0 & 0 & 0 & 0 & 0 & 0 & 0 & 0 & 0 & 0 & 0 & 0 & 2 & 0 & 0 & 0 & 0 & 2 & 0\end{array}$

$\begin{array}{lllllllllllllllllll}0 & 0 & 0 & 0 & 0 & 0 & 0 & 0 & 0 & 0 & 0 & 0 & 2 & 0 & 0 & 0 & 0 & 0 & 0\end{array}$

$\begin{array}{lllllllllllllllllll}0 & 0 & 0 & 0 & 0 & 0 & 0 & 0 & 0 & 0 & 0 & 0 & 0 & 0 & 0 & 0 & 0 & 0 & 2\end{array}$

$\begin{array}{lllllllllllllllllll}0 & 0 & 0 & 0 & 0 & 0 & 0 & 0 & 0 & 0 & 0 & 0 & 2 & 0 & 0 & 0 & 0 & 0 & 0\end{array}$

$\begin{array}{lllllllllllllllllll}0 & 0 & 0 & 0 & 0 & 0 & 0 & 0 & 0 & 0 & 0 & 0 & 1 & 0 & 0 & 1 & 1 & 0 & 1\end{array}$

\begin{tabular}{lllllllllllllllllll|l}
0 & 0 & 0 & 0 & 0 & 0 & 0 & 0 & 0 & 0 & 0 & 0 & 2 & 0 & 0 & 2 & 2 & 0 & 0 & P-B,S
\end{tabular}

$\begin{array}{lllllllllllllllllll}0 & 0 & 0 & 0 & 0 & 0 & 0 & 0 & 0 & 0 & 0 & 0 & 0 & 0 & 0 & 0 & 0 & 0 & 2\end{array}$

$\begin{array}{lllllllllllllllllll}0 & 2 & 2 & 0 & 0 & 0 & 0 & 0 & 0 & 0 & 0 & 0 & 0 & 0 & 0 & 2 & 0 & 0 & 0\end{array}$

$\begin{array}{lllllllllllllllllll}0 & 0 & 0 & 0 & 0 & 0 & 0 & 0 & 0 & 0 & 0 & 0 & 0 & 0 & 0 & 0 & 0 & 2 & 0 \\ \mathrm{P}\end{array}$

$\begin{array}{lllllllllllllllllll}0 & 2 & 0 & 0 & 0 & 0 & 0 & 0 & 0 & 0 & 0 & 0 & 0 & 0 & 0 & 0 & 0 & 0 & 0\end{array}$

$\begin{array}{lllllllllllllllllll}0 & 0 & 0 & 0 & 0 & 0 & 0 & 0 & 0 & 0 & 0 & 0 & 0 & 0 & 0 & 0 & 0 & 0 & 2\end{array}$

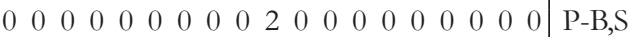

$\begin{array}{lllllllllllllllllll}2 & 0 & 0 & 0 & 0 & 0 & 0 & 0 & 0 & 0 & 0 & 0 & 0 & 0 & 0 & 0 & 0 & 2 & 0\end{array}$

$\begin{array}{llllllllllllllllllll}0 & 0 & 0 & 0 & 0 & 1 & 1 & 0 & 0 & 0 & 0 & 1 & 0 & 0 & 1 & 1 & 0 & 1 & 0 & \text { P-B }\end{array}$

$\begin{array}{lllllllllllllllllll}0 & 0 & 0 & 0 & 0 & 0 & 0 & 0 & 2 & 0 & 0 & 0 & 0 & 0 & 0 & 0 & 0 & 0 & 0\end{array}$

$\begin{array}{lllllllllllllllllll}0 & 0 & 0 & 0 & 0 & 0 & 0 & 0 & 0 & 0 & 0 & 0 & 0 & 0 & 0 & 0 & 2 & 0 & 0 \\ 0 & 0 & 0 & 0 & 0 & 0 & 0 & 0 & 0 & 0 & 0 & 0 & 0 & 0 & 0 & 0 & 0 & 2 & 0\end{array}$

$\begin{array}{llllllllllllllllllll}0 & 0 & 0 & 0 & 0 & 0 & 0 & 0 & 0 & 0 & 0 & 0 & 0 & 0 & 0 & 0 & 0 & 2 & 0 & \text { P-B }\end{array}$

$\begin{array}{llllllllllllllllllll}0 & 0 & 0 & 0 & 0 & 0 & 0 & 0 & 1 & 0 & 0 & 0 & 1 & 0 & 1 & 0 & 0 & 1 & 1 & \text { P-B,S }\end{array}$

$\begin{array}{lllllllllllllllllll}0 & 0 & 0 & 2 & 2 & 0 & 0 & 0 & 0 & 0 & 0 & 0 & 0 & 0 & 0 & 0 & 0 & 0 & 0 \\ \text { B,S }\end{array}$

$\begin{array}{lllllllllllllllllll}0 & 0 & 0 & 0 & 0 & 0 & 0 & 0 & 0 & 0 & 0 & 0 & 0 & 0 & 0 & 2 & 0 & 0 & 0\end{array}$

$\begin{array}{lllllllllllllllllll}0 & 0 & 0 & 0 & 0 & 0 & 0 & 0 & 0 & 0 & 0 & 0 & 0 & 0 & 0 & 0 & 2 & 0 & 0\end{array}$

\begin{tabular}{lllllllllllllllllll}
0 & 0 & 0 & 0 & 0 & 0 & 0 & 0 & 0 & 0 & 0 & 0 & 0 & 0 & 2 & 0 & 0 & 0 & 0 \\
\hline
\end{tabular}

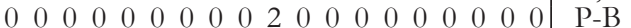

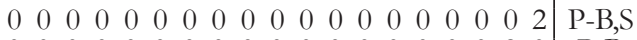

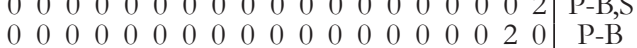

- aer

aer acf - - m -

- $\begin{array}{llll}\text { acf } & - & - & \text { o-m }\end{array}$

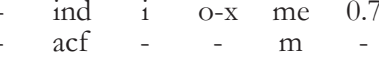

$\begin{array}{lllll}\text { st,aer acf } & - & \mathrm{x}-\mathrm{b} & \mathrm{O}-\mathrm{m} & 0.8\end{array}$

ind $\mathrm{hb} \quad \mathrm{O}-\mathrm{x} \quad \mathrm{m} \quad 0.6$

$\begin{array}{lllll}\text { acf } & - & 0-x & 0 & 0.6\end{array}$

$\begin{array}{llllll}- & \text { acf } & - & \text { o-x } & \text { m } & 0.6\end{array}$

st-str acf hb $\mathrm{x}-\mathrm{b}$ me 0.8

$\mathrm{o}-\mathrm{b} \quad-1.5$

ind $i \quad \mathrm{o}$ ot 1.00

$\begin{array}{lllll}\text { acf } & \mathrm{i} & \mathrm{x}-\mathrm{O} & \mathrm{O}-\mathrm{m} & 0.5\end{array}$

$\begin{array}{llll}\text { ind } \quad-\quad \mathrm{x}-\mathrm{O} & \mathrm{O}-\mathrm{m} & 0.4\end{array}$

$\begin{array}{lllll}- & - & - & - & - \\ - & - & \mathrm{o} & - & 1.1\end{array}$

acf $\mathrm{hb}-\mathrm{m}$

acf $-\quad-m$

$\begin{array}{ccccc}- & - & - & - & - \\ \text { ind } & - & \mathrm{o}-\mathrm{b} & \mathrm{m} & 1.5\end{array}$

$\begin{array}{ccccc}- & - & - & \mathrm{m} & - \\ \text { ind } & - & - & \mathrm{m} & -\end{array}$

st-str acf

st-str ind $\mathrm{i} \quad \mathrm{o} \quad \mathrm{O}-\mathrm{m} \quad{ }^{-} .2$

aer acf

- acf - - m

$\mathrm{o}-\mathrm{m}$

- ind - $\quad$ m

aer ind - $\mathrm{x}-\mathrm{O} \quad \mathrm{O}-\mathrm{m} \quad 0.5$

B

-B

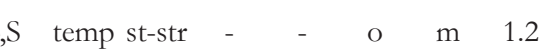

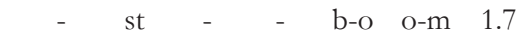

B - $\quad$ - $\quad$ ind $\quad \mathrm{i} \quad$ o-a $\quad$ o-m 1.8

$\begin{array}{ccccccc}- & \text { aer } & - & - & - & - & - \\ - & - & - & - & - & - & -\end{array}$

$\begin{array}{cccccc}\text { aer } & \text { alf } & \text { hl } & \text { x-b } & - & 0.8 \\ - & - & - & - & - & -\end{array}$

aer $\quad-\quad-\quad x-b \quad-0.9$

st $-\quad-\quad-\quad-$

-2
-

$\begin{array}{ccccc}\text { - } & \mathrm{mh} & \mathrm{O} & - & 1.3 \\ \text { ind } & \mathrm{i} & \mathrm{b}-\mathrm{O} & \mathrm{O} & 1.7\end{array}$

- ind $\mathrm{i}$ b-o $\mathrm{O}-\mathrm{m} 1.75$

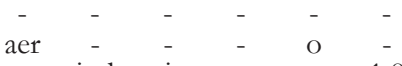

- ind i o-a me 1.8 acf $\quad-\quad x-b \quad$ o-m $\quad 0.9$

$\begin{array}{lllllll}\text { st-str } & - & - & \text { o } & \text { o } & 1.2\end{array}$

st-str - $\quad-\quad b \quad-\quad 2.3$ 


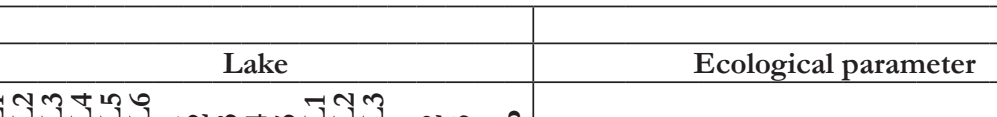

Taxa

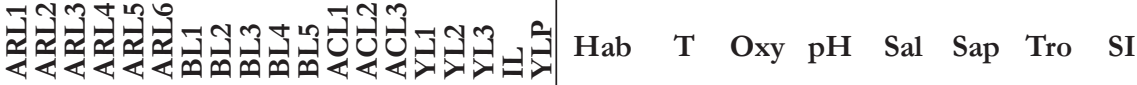

Oscillatoria subbrevis Schmidle

Oscillatoria tenuis C.Agardh ex Gomont

Phormidium acula (Brühl \& Biswas)

Anagnostidis \& Komárek

Phormidium hiemale (Jaag) Anagnostidis

Phormidium inundatum Kützing ex Gomont

*Phormidium stagninum Anagnostidis

Planktolyngbya tallingii Komárek \& H.Kling

Pseudanabaena galeata Böcher

Pseudanabaena limnetica (Lemmermann) Komárek

Rivularia sp.

* Scytonema coactile Montagne ex Bornet \& Flahault

Spirulina major Kützing ex Gomont

$\begin{array}{lllllllllllllllllll}0 & 0 & 0 & 0 & 0 & 0 & 2 & 0 & 0 & 0 & 0 & 0 & 0 & 0 & 0 & 0 & 2 & 0 & 0\end{array}$

$\begin{array}{llllllllllllllllllll}0 & 0 & 0 & 4 & 4 & 4 & 4 & 0 & 4 & 4 & 0 & 0 & 4 & 4 & 4 & 0 & 0 & 4 & 4 & \text { P- }\end{array}$

$\begin{array}{lllllllllllllllllll}0 & 0 & 0 & 0 & 0 & 0 & 0 & 0 & 0 & 0 & 0 & 0 & 0 & 0 & 0 & 0 & 0 & 2 & 0\end{array}$

$\begin{array}{lllllllllllllllllll}0 & 0 & 0 & 0 & 0 & 0 & 0 & 0 & 0 & 0 & 0 & 0 & 0 & 0 & 0 & 0 & 2 & 0 & 0\end{array}$

\section{CHLOROPHY'TA}

Asterococcus limneticus G.M.Smith

$\begin{array}{llllllllllllllllll}0 & 0 & 0 & 0 & 0 & 0 & 0 & 0 & 0 & 0 & 0 & 0 & 0 & 0 & 0 & 0 & 0 & 0 \\ 0 & 0 & 0 & 0 & 0 & 0 & 0 & 0 & 0 & 0 & 0 & 0 & 0 & 0 & 0 & 2\end{array}$

$\begin{array}{lllllllllllllllllll}0 & 0 & 0 & 0 & 0 & 0 & 0 & 0 & 0 & 0 & 0 & 0 & 0 & 0 & 0 & 2 & 0 & 0 & 0 \\ 0 & 0 & 0 & 0 & 0 & 0 & 0 & 0 & 0 & 0 & 0 & 0 & 0 & 0 & 0 & 0 & 0 & 0 & 2 \\ \mathrm{~B}, \mathrm{Ep}\end{array}$

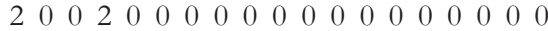

$\begin{array}{lllllllllllllllllll}0 & 0 & 0 & 0 & 0 & 2 & 0 & 0 & 0 & 0 & 0 & 2 & 0 & 0 & 0 & 0 & 0 & 0 & 2\end{array}$ P-B

$\begin{array}{lllllllllllllllllll}0 & 0 & 0 & 0 & 0 & 0 & 0 & 0 & 0 & 0 & 0 & 0 & 0 & 0 & 0 & 2 & 0 & 0 & 0\end{array}$

$\begin{array}{lllllllllllllllllll}0 & 2 & 0 & 0 & 0 & 0 & 0 & 0 & 0 & 0 & 0 & 0 & 0 & 0 & 0 & 0 & 0 & 0 & 0\end{array}$

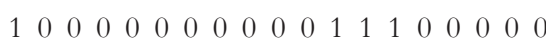

$\begin{array}{lllllllllllllllllll}3 & 0 & 0 & 0 & 0 & 0 & 3 & 0 & 3 & 0 & 0 & 0 & 0 & 3 & 0 & 3 & 3 & 3 & 3\end{array}$

Bulbochaete superbus (Cienkowski) Scherffel

* Chlamydomonas pertusa Chodat

Chloroidium ellipsoideum (Gerneck)

Darienko, Gustavs, Mudimu,

Menendez, Schumann, Karsten, Friedl
\& Proschold

*Coenochloris pyrenoidosa Korshikov

* Coenocystis tapasteana Komárek

Desmodesmus abundans (Kirchner)

E.Hegewald

Desmodesmus armatus var. longispina

(Chodat) E.Hegewald

Desmodesmus dispar (Brébisson)

E.Hegewald

Desmodesmus hystrix (Lagerheim)

E.Hegewald

Desmodesmus magnus (Meyen) Tsarenko

$\begin{array}{lllllllllllllllllll}0 & 0 & 0 & 0 & 0 & 0 & 0 & 0 & 0 & 0 & 0 & 2 & 0 & 0 & 0 & 0 & 0 & 0 & 0\end{array} \quad$ P-B

$\begin{array}{lllllllllllllllllll}0 & 0 & 0 & 0 & 0 & 0 & 0 & 0 & 0 & 0 & 0 & 0 & 2 & 0 & 0 & 0 & 0 & 0 & 0 \\ 0\end{array}$

$\begin{array}{llllllllllllllllllll}0 & 0 & 0 & 0 & 0 & 0 & 0 & 0 & 0 & 0 & 0 & 0 & 0 & 0 & 0 & 0 & 2 & 0 & 0 & P\end{array}$

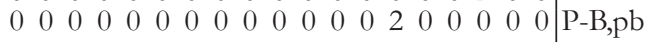

ko $\quad \begin{array}{lllllllllllllllllll}0 & 0 & 0 & 0 & 0 & 0 & 0 & 0 & 0 & 0 & 0 & 0 & 0 & 2 & 0 & 0 & 0 & 0 & 0\end{array}$ Glochiococcus aciculiferus (Lagerheim) P.C.Silva

Microspora sp.

Monoraphidium irregulare (G.M.Smith)

Komárková-Legnerová

Oedogonium sp.1

Oedogonium sp. 2

Pseudopediastrum boryanum (Turpin)

E.Hegewald var. boryanum

Pseudopediastrum boryanum var. cornutum (Raciborski) Tsarenko

Psendopediastrum boryanum var. longicorne (Reinsch) Tsarenko

Pseudopediastrum sp.

$\begin{array}{lllllllllllllllllll}0 & 0 & 0 & 0 & 0 & 0 & 0 & 0 & 0 & 0 & 0 & 0 & 0 & 2 & 0 & 0 & 0 & 0 & 0\end{array}$

$\begin{array}{llllllllllllllllllllllllllllllll}0 & 0 & 0 & 0 & 0 & 0 & 0 & 0 & 0 & 0 & 0 & 0 & 0 & 0 & 0 & 0 & 2 & 0 & 0\end{array}$

$\begin{array}{llllllllllllllllllll}0 & 0 & 0 & 0 & 0 & 0 & 0 & 0 & 0 & 0 & 0 & 1 & 1 & 0 & 0 & 1 & 1 & 1 & 0\end{array}$

$\begin{array}{lllllllllllllllllll}0 & 0 & 0 & 0 & 0 & 0 & 0 & 0 & 0 & 0 & 0 & 0 & 2 & 0 & 0 & 0 & 0 & 2 & 0\end{array}$

$\begin{array}{lllllllllllllllllll}0 & 0 & 0 & 0 & 0 & 0 & 0 & 0 & 0 & 0 & 0 & 0 & 0 & 2 & 0 & 0 & 0 & 0 & 0\end{array}$ P-B

\begin{tabular}{|c|c|c|c|c|c|c|c|}
\hline - & - & - & - & - & - & - & - \\
\hline $\mathrm{B}, \mathrm{S}$ & - & st-str & - & hl & $\mathrm{a}-\mathrm{O}$ & me & 2.6 \\
\hline
\end{tabular}

$\begin{array}{lllllllllllllllllll}0 & 0 & 2 & 0 & 0 & 0 & 0 & 0 & 0 & 0 & 0 & 0 & 0 & 0 & 0 & 0 & 0 & 0 & 0\end{array}$ $\begin{array}{lllllllllllllllllll}0 & 0 & 0 & 0 & 0 & 0 & 0 & 0 & 0 & 0 & 0 & 0 & 0 & 0 & 0 & 2 & 0 & 0 & 0\end{array}$

$\begin{array}{lllllllllllllllllll}0 & 0 & 0 & 0 & 0 & 0 & 0 & 0 & 0 & 0 & 0 & 0 & 2 & 2 & 0 & 0 & 0 & 0 & 0\end{array}$ $\begin{array}{llllllllllllllllllll}0 & 0 & 0 & 0 & 0 & 0 & 0 & 0 & 0 & 0 & 0 & 0 & 0 & 2 & 0 & 0 & 0 & 0 & 0\end{array}$

$\begin{array}{lllllllllllllllllll}3 & 0 & 0 & 0 & 0 & 0 & 0 & 3 & 0 & 0 & 0 & 3 & 3 & 3 & 0 & 3 & 3 & 3 & 3\end{array}$ $\begin{array}{llllllllllllllllllllllllllll}0 & 0 & 0 & 0 & 0 & 0 & 0 & 0 & 0 & 0 & 0 & 0 & 0 & 0 & 0 & 0 & 0 & 0 & 2\end{array}$

$\begin{array}{lllllllllllllllllll}0 & 0 & 0 & 0 & 0 & 0 & 3 & 0 & 0 & 3 & 0 & 3 & 3 & 3 & 0 & 3 & 3 & 0 & 3\end{array}$

$\begin{array}{llllllllllllllllllll}0 & 0 & 0 & 0 & 0 & 0 & 0 & 0 & 0 & 0 & 0 & 0 & 0 & 0 & 0 & 0 & 2 & 0 & 0\end{array}$

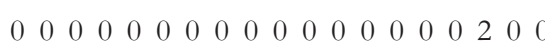

$\begin{array}{llllllllllllllllllll}0 & 0 & 0 & 0 & 0 & 0 & 0 & 0 & 0 & 0 & 0 & 0 & 0 & 0 & 0 & 0 & 2 & 0 & 0\end{array}$

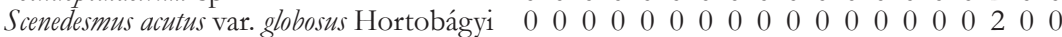

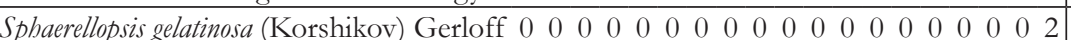

Tetradesmus dimorphus (Turpin) M.J.Wynne

Tetradesmus obliquus (Turpin) M.J.Wynne

Tetraëdron lobulatum var. polyfurcatum

G.M.Smith

Tetraëdron minimum (A.Braun) Hansgirg

Ulothrix aequalis Kützing

$\begin{array}{lllllllllllllllllll}0 & 2 & 0 & 0 & 0 & 0 & 0 & 0 & 0 & 0 & 0 & 2 & 2 & 0 & 0 & 0 & 0 & 0 & 0 \\ 0 & 0 & 0 & 0 & 0 & 0 & 0 & 2 & 0 & 0 & 0 & 2 & 0 & 0 & 0 & 0 & 0 & 0 & 0\end{array}$

$\begin{array}{lllllllllllllllllll}0 & 0 & 0 & 0 & 0 & 2 & 0 & 0 & 0 & 0 & 0 & 0 & 0 & 0 & 0 & 0 & 2 & 0 & 0\end{array}$

$\begin{array}{lllllllllllllllllll}0 & 0 & 0 & 0 & 0 & 0 & 0 & 0 & 0 & 0 & 0 & 0 & 0 & 0 & 0 & 0 & 0 & 0 & 2\end{array}$

$\begin{array}{lllllllllllllllllll}0 & 0 & 0 & 0 & 0 & 0 & 0 & 0 & 0 & 0 & 0 & 0 & 0 & 2 & 0 & 0 & 0 & 0 & 0\end{array}$

$\begin{array}{cccccc}- & - & - & - & - \\ - & - & - & - & -\end{array}$

- aer - $\quad$ - $\quad$ o $\quad$ o-m 1.3

$\begin{array}{ccccccc}- & - & - & - & - & \mathrm{O}-\mathrm{m} & - \\ - & - & - & - & - & - & -\end{array}$

$\begin{array}{llllllll} & - & - & - & - & \mathrm{a} & \mathrm{e} & 3.3 \\ \mathrm{~B} & - & - & - & - & \mathrm{b} & \mathrm{e} & 2.2\end{array}$

\begin{tabular}{lllllll}
- & - & - & - & - & - & - \\
\hline
\end{tabular}

-B,S warm st $\quad-\quad$ hl a $\quad-\quad 3.4$

Ulothrix zonata (F.Weber \& Mohr) Kützing

\section{EUGIENOZOA}

Phacus curvicauda Svirenko

$\begin{array}{lllllllllllllllllll}0 & 0 & 0 & 0 & 0 & 0 & 0 & 0 & 2 & 0 & 0 & 0 & 0 & 0 & 0 & 0 & 0 & 0 & 0\end{array}$

Phacus limnophilus (Lemmermann) E.W.Linton

\& A.Karnkowska-Ishikawa

$\begin{array}{lllllllllllllllllll}0 & 0 & 0 & 0 & 0 & 0 & 0 & 0 & 2 & 0 & 0 & 0 & 0 & 0 & 0 & 0 & 0 & 0 & 0\end{array}$

(1)

Trachelomonas bacillifera var. minima Playfair

Trachelomonas curta A.M.Cunha

Trachelomonas stokesiana T.C.Palmer

Trachelomonas superba Svirenko

$\begin{array}{lllllllllllllllllll}0 & 0 & 0 & 2 & 0 & 2 & 0 & 0 & 0 & 0 & 0 & 0 & 0 & 0 & 0 & 0 & 0 & 0 & 0\end{array}$

$\begin{array}{lllllllllllllllllll}0 & 0 & 0 & 0 & 0 & 0 & 0 & 0 & 0 & 0 & 0 & 0 & 0 & 0 & 0 & 0 & 0 & 0 & 2\end{array}$

$\begin{array}{lllllllllllllllllll}2 & 0 & 0 & 0 & 0 & 0 & 0 & 0 & 0 & 0 & 0 & 0 & 0 & 0 & 0 & 0 & 0 & 0 & 0\end{array}$

Trachelomonas volvocina (Ehrenberg)

Ehrenberg var. volvocina

Trachelomonas volvocina var. derephora

$\begin{array}{lllllllllllllllllll}3 & 0 & 3 & 0 & 3 & 0 & 3 & 0 & 3 & 0 & 0 & 3 & 0 & 0 & 3 & 3 & 0 & 3 & 3\end{array}$

$\begin{array}{lllllllllllllllllll}0 & 0 & 0 & 2 & 0 & 0 & 2 & 0 & 0 & 0 & 0 & 0 & 0 & 0 & 0 & 0 & 0 & 0 & 0\end{array}$

$\begin{array}{cccccccc}- & - & - & - & - & \mathrm{b} & - & 2.2 \\ \mathrm{P} & - & - & - & - & \mathrm{b} & - & 2.00 \\ - & - & - & - & - & \mathrm{b} & - & 2.3 \\ \text { P-B } & - & \text { st-str } & \text { ind } & \mathrm{i} & \mathrm{b} & - & 2.05 \\ - & - & - & - & - & - & - & - \\ \text { P-B } & - & \text { st-str } & - & \text { i } & \text { b } & - & 2.1 \\ \text { B } & - & - & - & - & \text { o } & - & 1.3 \\ \text { P-B } & - & \text { st-str ind } & \text { i } & \text { o-a } & - & 1.8\end{array}$

Trachelomonas volvocina var. punctata Playfair $\begin{aligned} & 0 \\ & 0\end{aligned}$

P-B - st ind $\mathrm{i} \quad \mathrm{b} \quad-\quad 2.25$

P-B eterm st-str - $\quad$ - o-b - 1.5

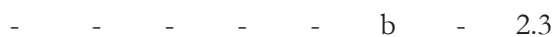

$\begin{array}{lll}\mathrm{b} & - & 2.3 \\ \mathrm{~b} & - & 2.1\end{array}$

b $\quad-\quad 2.2$

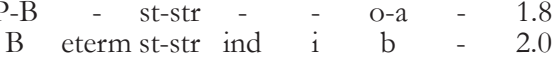

b $\quad-\quad 2.0$ 